\title{
ISTORICUL ŞI STADIUL ACTUAL AL CERCETĂRILOR ARHEOLOGICE EFECTUATE PE SITUL “CETATE” DE LA ZIMNICEA
}

Daniel Spânu

Motto: "... oser s'exposer à se tromper

est une des vertues de l'archéologie ..."

(Bertrand A. 1876, 5)

\section{FORSCHUNGSGESCHICHTE UND FORSCHUNGSSTAND DER FUNDSTELLE „CETATE” (BURG) VON ZIMNICEA}

\section{Zusammenfassung}

Veröffentlichte Mitteilungen über die Fundstelle „,Cetate” von Zimnicea. Die Mitteilungen über die Fundstelle „Cetate" von Zimnicea sind mit einer überraschenden Sparsamkeit in der Fachliteratur, durch zwei kurze Grabungsberichte und mehrere Andeutungen in verschiedenen Beiträgen eingeführt worden, und das trotz den hier durchgeführten 12 Grabungskampagnen: 1924 (I. Andrieşescu), 1948-1949 (I. Nestor) und 1967-1975 (A. D. Alexandrescu). Von den Materialien, die wahrscheinlich bei der Fundstelle „Cetatea" während dieser Grabungen geborgen worden sind, wurden in der Fachliteratur nur unerhofft wenig keramische Stücke systematisch (abgebildet und beschrieben) vorgelegt und das Dank den Einsätze von Vasile Pârvan, Irina Casan-Franga und Dumitru Tudor und nicht der Grabungsleiter der verschiedenen Grabungsteams.

Die bislang publizierten Ergebnisse haben gezeigt, dass in der Fundstelle „Cetate" Spuren dreier unterschiedlicher Zeitspannen belegt werden, können und zwar hallstattzeitliche Grabfunde, die von einer sehr intensiven, die fast die ganze Latènezeit andauernden Besiedlung gestört wurden und die ihrerseits von einer mittelalterlichen Dorfsiedlung des 14. - 15. Jahrhundert überlagert war. Gleichzeitig scheint die Stratigraphie der Fundstelle sehr komplex zu sein, in manchen Stellen bis zu einer Tiefe von $4 \mathrm{~m}$.

Obwohl die Morphologie des Geländes den Einheimischen aber auch den Archäologen immer die Existenz von Befestigungsanlagen suggeriert hat, wurden in der Fachliteratur niemals Befestigungssysteme erwähnt und das trotz den hier lang andauerten durchgeführten Forschungen. Bezüglich der Unebenheiten im Gelände, die als Verteidigungswall gedeutet wurden, konnte die Forschung bislang ihren anthropischen Charakter nicht belegen. Dagegen konnten Informationen über die Ausdehnung der latènezeitlichen Besiedlung auch jenseits dieser „Schutzgraben" gebracht werden, die alle einfache Graben darstellen, die durch die natürliche (oder auch anthropisch-moderne) Erosion des einheimischen Löss aus dem die hohe, über die Donauaue liegende Terrasse gebildet ist, entstanden sind.

Die älteren Forschungen konnten die Kennzeichen jener, leider nicht weiter präzisierten Bauten aus Holz und Steinen, von großen Dimensionen (die I. Nestor von „Türmen" oder „Paläste" zu sprechen bewogen haben) erläutern, deren Reste nur in den Schnitten I und II identifiziert wurden. Nach den Indizien der Fachliteratur (sowohl von Pârvan, als auch von Nestor), wurden für die Errichtung der, innerhalb der latènezeitlichen Siedlung identifizierten Anlagen, Holzbalken, Steine für die Fundamente und eventuell Schilf benützt (Strohlehm wird nicht erwähnt). Manchmal hat A. D. Alexandrescu auch Dachziegel, schon für die erste Hälfte des I. Jahrhunderts v. Chr. erwähnt (was hypothetisch der IV Schicht aus der Siedlung entsprechen würde), doch scheint diese Behauptung mehr fraglich als glaubwürdig zu sein. Die Siedlungsstratigraphie wurde historisiert von A. D. Alexandrescu gedeutet, aber technischer und ausführlicher von Ion Nestor und Radu Vulpe beschrieben.

In der von I. Nestor vorgeschlagener Schema, enthält die Stratigraphie der Fundstelle „Cetate" vier Siedlungsschichten, von denen die drei unteren mit Datierungselemente des 4. - 3. Jahrhundert v. Chr.: griechische (attische) Luxuskeramik, gestempelte Amphoren, eine thrakische Fibel und das Bruchstück 
eines Deckels mit dem Eindruck einer solchen Fibel in der weichen Pasta. Die obere Schicht (Schicht IV) scheint Datierungselemente zu enthalten, die in der aktuellen Forschung als kennzeichnende chronologische Indikatoren für den Ausgang des 2. und der ersten Hälfte des 1. Jahrhunderts a.Chr. betrachten werden. Dazu gehören, unter andern, die einheimischen Nachahmungen der delischmegarischen Becher. Im allgemeinen kann in der Forschung die Dürftigkeit der Argumentation der Synchronisierung zwischen den Siedlungs- und Bestattungsphasen beobachtet werden, doch niemals wurde sie widerlegt: die wenigen, auf der „Cetate" geborgenen und in der Literatur erwähnten Materialien sind aussagekräftig in dieser Richtung.

Fragen, die von der älteren Forschung nicht gelöst wurden. Trotz einer anscheinenden Umschreibung auf Grund geomorphologischen Kriterien der latènezeitlichen Siedlung von Zimnicea, muss hervorgehoben werden, dass die Grenzen der latènezeitlichen Besiedlung nicht genügend präzisiert wurden. Aus diesem Blickwinkel sollte sogar die traditionelle Trennung des westlich vom heutigen Zimnicea liegendes Gelände zwischen „Cetate" und „Câmpul Morților“ („Feld der Tode“), mit einer gewissen Enthaltung betrachtet werden.

Bei der Abwesenheit von publizierten Profilen der erforschten Schnitte fehlt der aktuellen Forschung ein konkludentes und vor allem konkretes Bild der Stratigraphie der getischen Siedlung von Zimnicea; dazu noch erschwert die Unmöglichkeit der Rekonstruktion der stratigraphischen Lage von chronologisch aussagekräftigen Funden, wie z. B. die gestempelten Amphoren, eine eventuelle vertiefte Verarbeitung der gegenwärtigen Quellenlage. Bedeutende chronologische Indikatoren, wie die griechischen Amphoren, aber auch die Becher mit Reliefverzierung können nur hypothetisch mit dem von I. Nestor vorgeschlagenes stratigraphisches Schema in Beziehung gebracht. Beim jetztigen Forschungsstand stehen uns keine konsistente Argumente für eine ununterbrochenen Besiedlung auf der „Cetatea" von Zimnicea vom 4. und bis im 1. Jahrhundert v.Chr. (oder sogar bis im 1. Jahrhundert n.Chr.?) zur Verfügung; im selben Maß können aber auch mögliche Diskontinuitäten nicht argumentiert werden.

Schlusswörter: Hallstattzeit, Latènezeit, Mittelalter, Siedlung, Forschungs geschichte.

Cuvinte cheie: prima epocă a fierului, a doua epocă a fierului, evul mediu, aşezare, istoricul cercetării

\section{Introducere}

Reluarea săpăturilor pe situl "Cetate" de la Zimnicea, jud. Teleorman de către un colectiv aflat sub coordonarea lui Mircea Babeş $^{1}$ şi mai ales proiectata pregătire a unui raport general asupra campaniilor de cercetări desfăşurate în ultimii ani ${ }^{2}$ presupuneau mai

\footnotetext{
${ }^{1}$ Din colectiv au făcut parte pe parcursul celor cinci campanii desfăşurate până acum (2000-2004) o serie de arheologi tineri şi, poate, mai puțin bătrâni, de la mai multe instituții de profil: Institutul de Arheologie "Vasile Pârvan" (Mircea Babeş, Despina GugiuMăgureanu, Daniel Spânu), Facultatea de Istorie a Universității Bucureşti (Mircea Babes), Muzeul Național de Istorie a României (George Trohani), Muzeul Judetean Teleorman din Alexandria (Ion Pătraşcu), Muzeul Județean de Istorie din Piteşti (Dragoş Măndescu), Muzeul de Istorie din Oltenița (Bogdan Şandric). Țin să mulţumesc pe această cale Silviei Marinescu-Bîlcu, precum şi colegilor mei Dragoş Măndescu şi Ion Pătraşcu pentru sugestiile utile oferite în vederea redactării contribuției de față.

${ }^{2}$ Rezultatele săpăturilor din ultimii ani, publicate ca rezumate extrem de succinte în Cronicile anuale ale săpăturilor arheologice din România, nu au fost incluse în demersul de față (Babeş et alii 2001, 2002; Spânu,
}

întâi o privire retrospectivă asupra strădaniilor mai vechi care au transformat acest sit într-unul atât de renumit. Demersul de faţă se doreşte a fi tocmai un anunț şi o introducere a preconizatului raport general comun. Pe de altă parte, aşa cum se va putea desprinde din cele ce urmează, informațiile legate de cercetările mai vechi efectuate pe situl "Cetate" au fost publicate în mod relativ disparat, uneori, la intervale mari de timp, astfel că o sintetizare a acestora poate fi considerată necesară. Mai trebuie precizat că demersul de față vizează exclusiv situl amintit ("Cetate"), cu locuirile sale protoistorică şi medievală şi nu zonele înconjurătoare, denumite, în virtutea unei tradiții istoriografice care coboară în timp până la Bolliac, dar şi a spectaculoaselor descoperiri cu caracter funerar de aici, "Câmpul morților" (fig. 1).

Trohani 2003; Spânu 2004), ele urmând să constituie, după cum tocmai am arătat, obiectul unui demers separat. 


\section{Săpăturile din secolul al XIX-lea şi rezultatele lor}

In ciuda metodelor primare de cercertare de teren, săpăturile întreprinse de Cesar Bolliac la începutul anilor '70 ai secolului al XIX-lea iau permis acestuia să identifice două categorii de ansambluri preistorice distincte aflate la vest de localitatea Zimnicea, şi anume o aşezare şi o necropolă. Incă din acel stadiu cu totul incipient al informațiilor, vestigiile care au atras mai mult atenția au fost înmormântările preistorice care furnizau materiale mai spectaculoase, aşa cum este cunoscutul pythos ornamentat cu rozete și cavaleri ${ }^{3}$. Observația lui Tocilescu, potrivit căruia cea mai importantă necropolă preistorică de pe teritoriul anticei Dacii ar fi cea de la Zimnicea (Tocilescu 1880, comentat în acest sens şi de Alexandrescu 1980), avea să se confirme şi să-şi păstreze pentru mult timp valabilitatea. Fascinația de sorginte romantică pentru morminte avea să eclipseze interesul pentru cercetarea locuirii preistorice de la Zimnicea.

Singura informație concretă de care dispunea Tocilescu la data conceperii celui dintâi tratat românesc de preistorie a Daciei, bazată pe observațiile lui Bolliac, era aceea că la Zimnicea se afla o "cetate intarita cu pamentu ridicatu d'in immense si profunde sianturi, lung. 200, latime 150 pasi ..." (Tocilescu 1880) ${ }^{4}$. In mod evident o asemenea constatare se baza exclusiv pe observarea superficială a terenului şi nu pe cercetări concrete ale "Cetății". Pe de altă parte, însuşi Bolliac ezita să dateze "Cetatea", considerând că în jurul acesteia (mai precis în afara

\footnotetext{
${ }^{3}$ Ilustrat şi descris încă de Bolliac 1872, 1, apoi de Tocilescu 1880, 581, tab. K, fig. 1/14, recipientul de tip pythos a fost în repetate rânduri reprodus în literatura mai recentă (v. Moscalu 1983, 93-94, 299, n. 1164 cu literatura). Chiupul a fost descoperit cu mare probabilitate în necropola getică, iar informația potrivit căreia el ar proveni dintr-o fântână a "Cetății" (Iosifaru 2003, 36) este mai degrabă fictivă. Asupra datei probabile a descoperirii spectaculosului recipient (1871 ?), Măndescu 2001, 18-19.

4 Informații legate de săpăturile lui Bolliac pe "Cetatea" de la Zimnicea şi mai ales de rezultatele lor sunt încă inedite. După cum arată şi Măndescu 2001, 17, reeditarea integrală a numeroaselor scrieri arheologice semnate de Bolliac, şi, ar trebui adăugat, poate şi publicarea unora încă inedite, nu constituie o întreprindere lipsită de interes.
}

şanțurilor) s-ar fi întins un "orasiu dacu" (Bolliac 1872, citat şi de Tocilescu 1880).

Ca şi săpăturile lui Bolliac, denumite atât de plastic de către Nestor "dezgropări", săpăturile mai vechi ale amatorilor şi pasionaților de antichități Papazoglu şi Butculescu nu au avut nici ele ca scop decât completarea colectiilor lor particulare cu piese spectaculoase identificate în teren (Nestor 1949, 157; Alexandrescu 1980, 19) ${ }^{5}$. Amplasamentul acestor vechi săpături a rămas necunoscut, astfel că nu se poate preciza la ora actuală dacă ele vor fi atins sau nu "Cetatea".

\section{Cercetările interbelice şi rezultatele lor}

In cadrul programului de cercetare a siturilor preistorice de la Dunărea de Jos, Vasile Pârvan a determinat prin intermediul lui Ion Andrieşescu inițierea unei campanii de săpături sistematice în aşezarea preistorică de la Zimnicea. In Getica se arăta că cercetările lui Andrieşescu s-au desfăşurat în 1924 şi că rezultatele lor urmau să fie publicate în Dacia (Pârvan 1926, 608, nt. 1). Putem bănui că moartea lui Pârvan a determinat abandonarea valorificării vestigiilor de la Zimnicea, astfel că Nestor afirma pe bună dreptate două decenii şi jumătate mai târziu că "mare lucru nu se publicase din aceste cercetări mai vechi (...). Niciuna din aceste săpături (Nestor se referea şi la săpăturile lui Bolliac şi la cele ale lui Andrieşescu - n.n.) nu a reuşit să lumineze suficient şi bine intemeiat problemele fundamentale" ale sitului ${ }^{6}$. In ciuda tonului critic al lui Nestor, trebuie precizat că în Getica lui Pârvan au fost inserate o serie de informații disparate, dar consistente, care reflectau rezultatele cercetărilor conduse de Andrieşescu şi care, din perspectiva cercetării actuale, îşi păstrează în mare măsură valabilitatea.

\footnotetext{
${ }^{5}$ Potrivit lui Vulpe 1966, 19 şi Babeş et alii 2001, 276, Butculescu ar fi întreprins săpături la Zimnicea în jurul anului 1885.

${ }^{6}$ Din păcate, documentația săpăturilor lui Andrieșescu s-a pierdut, iar locația suprafețelor cercetate în 1924 a fost numai sumar precizată de Nestor I. 1949, 118 ("colțul de NE al platformei a fost străbătut în $1924 \mathrm{cu}$ şanțuri înguste"). Poziția sondajelor lui Andrieşescu nu a fost indicată (sau nu a mai putut fi ?) nici în planurile de situație publicate de Nestor 1949, 117 şi 1950, 99 şi nici în planul publicat de Alexandrescu 1980, 57, fig. 1.
} 
Unele informații sumare, legate nu atât de rezultatele săpăturilor din 1924, ci de modul în care acestea s-au desfăşurat sunt relatate cu pasiune juvenilă de către Vladimir Dumitrescu (Dumitrescu 1993, 47-52) ${ }^{7}$, la care se mai pot adăuga şi câteva referiri indirecte pe care le regăsim în catalogul amforelor ştampilate din spațiul românesc-extracarpatic redactat mai bine de patru decenii mai târziu de Dumitru Tudor. Fragmentele de amfore descoperite în 1924 provin fie din suprafața "A", fie din suprafața "B", ambele prelungindu-se cu şanțuri adiacente (Tudor 1967, 72-73) ${ }^{8}$. Din memoriile lui Dumitrescu aflăm că Andrieşescu trasase în interiorul "Cetății", mai precis în colțul ei de nord-est, o suprafață dreptunghiulară "de cel puțin 20-30 metrii, din care porneau spre val trei şanțuri lungi ce se opreau însă pe coama valului, fără să treacă dincolo de el" (Dumitrescu 1993, 51). Din relatările lui Dumitrescu nu aflăm dacă săpătura a fost epuizată, fapt puțin probabil dacă luăm în considerare întinderea mare a suprafeței deschise, numărul redus de numai zece muncitori (prea puțin impresionați de autoritatea lui Dumitrescu), durata de numai trei săptămâni a campaniei, precum şi absența îndelungată a lui Andrieşescu de pe şantier. Trebuie remarcat faptul că nici în perioada săpăturilor lui Nestor (v. infra) şi, cu atât mai mult, nici astăzi, suprafața de cca $600 \mathrm{mp}$ (?) deschisă de Andrieşescu nu a putut fi localizată, un indiciu în plus pentru adâncimea redusă până la care va fi progresat săpătura la finele campaniei din 1924. Prin urmare, putem lesne bănui că sistemul de fortificații nu a putut fi nici secționat şi nici studiat temeinic. Singura piesă, la care Dumitrescu face referire în memoriile sale, mai degrabă ca la o curiozitate, este o "mănuşe de amformă grecească pe a cărei ştampilă se aflau semne ce mi s-au părut cam $<$ cabalistice>, cum nu mai văzusem pe puținele ştampile de amfore de la Muzeu" (Dumitrescu

\footnotetext{
${ }^{7}$ La campania din 1924, se desfăşurase în lunile augustseptembrie (în acest sens v. şi Dumitrescu 1934, 123, n. 5), ar mai fi participat ca studenți, în afară de Vladimir Dumitrescu şi Vasile Christescu, Dorin Popescu şi Gheorghe Ştefan.

${ }^{8}$ Aşa cum reiese din descrierea locului de proveniență al fragmentului de amforă de Rhodos nr. 128, cel puțin suprafața B s-ar fi continuat cu patru şanțuri "adiacente".
}

1993, 51). Prin urmare, informații edite, mai consistente relative la cercetarea din 1924 trebuie căutate tot în Getica lui Pârvan.

Problema fortificațiilor. Pârvan considera că "un sat e în aceiaşi vreme un mic fort întărit", şi enumera şi "Cetatea" de la Zimnicea alături de alte astfel de "sate", precum cele de la Poiana sau Tinosu. Potrivit mențiunilor lui Pârvan, fortificațiile ar fi constat dintr-un val şi un şanţ, cu precizarea că la Zimnicea "nici măcar o ardere mai intensă nu se poate constata în val" (Pârvan 1926, 133, 470 şi 471). Trebuie însă subliniat faptul că afirmațiile lui Pârvan nu erau susținute în mod concret de $\mathrm{o}$ infrastructură documentară consistentă, ca în cazul săpăturilor de la Tinosu (Vulpe, Dunăreanu-Vulpe 1924, 166-223), ci se bazau, după toate probabilitățile, pe concluziile imprecise şi inedite ale sondajelor lui Andrieşescu ${ }^{9}$. Se poate bănui că elementul decisiv care pleda pentru postularea existenței unor fortificații (formate din val şi şanț) era oferit, nu atât de observațiile realizate în săpături, ci mai ales de configurația complexă a terenului. Aşa cum avea să remarce mai târziu Ion Nestor, morfologia sitului - un "promontoriu separat de restul malului printr-un şanț adânc" - este susceptibilă de a fi interpretată ca punct fortificat, pe care localnicii "îl numesc prin tradiție $<$ Cetate $>$ ". După cum observa cu o subtilă ironie Nestor, arheologul nu ar fi avut nevoie "de alte indicii, în fața unei astfel de situații (din teren - n.n.), pentru a-şi da seama că aici se află o aşezare străveche întărită..." (Nestor 1949, 116-117) ${ }^{10}$. Astfel de motive îl vor fi determinat şi pe Pârvan, asemeni lui Tocilescu după Bolliac, să considere că aşezarea getică de la Zimnicea ar fi fost fortificată.

Locuințe. Din cercetările lui Andrieşescu, Pârvan reținuse faptul că pentru construirea locuințelor s-ar fi întrebuințat trestia "nu numai pentru coperişuri, ci şi pentru pereții caselor,

\footnotetext{
9 In privința metodei de săpătură aplicate de Andrieşescu, Nestor 1949, 118 afirma că aceasta a presupus trasarea unor şanţuri înguste, în care contextele identificate (resturi de lemn masiv şi aglomerări de pietre) nu au fost urmărite atent şi nici nu au fost fixate precis pe vreun plan.

10 Rezultatele săpăturilor lui Nestor aveau însă să contrazică această impresie.
} 
construiți după maniera gardurilor de trestie din regiunile băltoase... In schimb pentru temelii şi vetre găsim aici frecvent întrebuințate blocuri informe de piatră" (Pârvan 1926, 467). Din perspectiva cercetărilor ulterioare, aceste observații legate de modul de amenajare a locuințelor îşi vădesc valabilitatea. Totuşi, se poate pune întrebarea dacă nu cumva se vor fi confundat resturile locuirii medievale cu cele de epocă Latène, mai ales atunci când se menționează folosirea piroanelor pentru construcții ${ }^{11}$. In absența unei cercetări minuțioase de teren şi a unei documentații amănunțite, informațiile legate de locuințele Latène de la Zimnicea erau încă ambigue şi pasibile de interpretări eronate.

Materiale reprezentative. Cercetările lui Andrieşescu au scos la lumină o serie de materiale care i-au atras atenția lui Pârvan şi care au servit în mod nemijlocit încadrării cronologice, în cea de a doua epocă a fierului, a locuirii getice de la Zimnicea. Lui Pârvan îi era cunoscută prezența în aşezarea de la Zimnicea a unor materiale ceramice de import, şi anume "numeroase resturi de amfore greceşti şi pontice", unele dintre ele databile pe baza ştampilelor "încă înainte de a. 200 a.Chr." şi care în parte erau importuri rhodoiene (Pârvan $1926,137,467,590)^{12}$. Alături de acestea se mai menționau şi un kantharos "attic" (Pârvan 1926, 590, 595, fig. 459) sau diferite fragmente ceramice cu phyrnis negru (Pârvan 1926, 608). Pârvan remarcase şi prezenţa unor cupe

\footnotetext{
${ }^{11}$ Referirea lui Pârvan 1926, 299, în privința folosirii piroanelor pentru construcțiile de lemn getice este suspectă. Cercetările recente au confirmat existența unor piroane la Zimnicea, dar în locuinţele medievale şi nu în cele de epocă Latene. In privință folosirii stufului, nu la locuințe preistorice ci la cele medievale: Nestor $1949,120$.

12 Pârvan făcea referire la acele amfore ştampilate care aveau să fie publicate în mod sistematic patru decenii mai târziu (!), la recomandarea lui Nestor de către Tudor 1967, 71-73, nr. 126-128, 131-135 şi 138, mai puțin cea cu "semne cabalistice" menționată de Vladimir Dumitrescu şi care se pierduse în 1927 (v. supra n. 14). Intr-adevăr, proveniența amforelor de la Zimnicea se dovedea a fi variată, Dumitru Tudor identificând mai multe centre de proveniență (Thasos, Rhodos, Cos, Sinope şi Heracleea Pontică). Trebuie remarcat faptul că la data redactării Geticii, Pârvan era minuțios documentat în privința materialelor de import identificate în săpătura lui Andrieşescu.
}

“deliene" (Pârvan 1926, 562, 590) ${ }^{13}$ şi sugera că acestea puteau fi produsele locale ale unui ipotetic atelier din aşezarea de la Zimnicea (Pârvan 1926, 209-210). Tot în aşezare s-ar fi descoperit şi "minunat profilate vase celtice" (Pârvan 1926, 562), prin această formulare înțelegându-se probabil ceramica locală de bună calitate produsă în epocă Latène. Trebuie subliniat faptul că Pârvan a găsit cu cale să reproducă unele fragmente ceramice locale, precum şi cupa-kantharos de import (Pârvan 1926, 576, fig. 414; 579, fig. 419; 583, fig. 435; 587, fig. 444; 595, fig. 459), acestea rămânând până astăzi printre puținele materiale ceramice din aşezarea getică de la Zimnicea care s-au bucurat de ilustrare în literatura de specialitate.

\section{Cercetările coordonate de Ion Nestor în 1948-1949 şi rezultatele lor}

Aveau să treacă mai bine de două decenii până la reluarea cercetărilor din aşezarea de la Zimnicea. In contextul reorganizării cercetării după principiile şi directivele culturale ale regimului instaurat după cel de al II-lea Război Mondial, Zimnicea a avut şansa să devină, de această dată la iniţiativa lui Ion Nestor, unul dintre puținele "şantiere de concentrare" (aşa cum mai era numai cel de la Pălatca, jud. Cluj) destinate cercetării preistorice, în care era reunit un colectiv numeros de cercetători ${ }^{14}$. Cu toate acestea, noile cercetări de la Zimnicea efectuate atât pe "Cetate", cât şi pe "Câmpul morților" (fig. 1), aveau să se desfăşoare numai pe durata a două campanii, respectiv 20 iunie -10

\footnotetext{
${ }^{13}$ Descoperirea unor cupe cu decor în relief la Zimnicea în campania din 1924 este menționată în treacăt şi de Dumitrescu 1934, 123.

${ }^{14}$ Potrivit lui Vulpe 1966, 19, cercetările de la Zimnicea reprezentau în acea perioadă principalul şantier al Muzeului Naţional de Antichităţi. Colectivul din 1949 reunea, în afara responsabilului de şantier, nu mai puţin de 10 perosane calificate, dintre care unele aveau să devină nume sonore ale cercetării arheologice postbelice şi anume, Alexandrina Alexandrescu, N. Adăniloaiei, Bucur Mitrea, Ion Barnea, Irina Casan, A. Nițu, P. Polonic, M. Pauncev şi Vlad Zirra (Nestor 1950, 102). Asupra componenței colectivului campaniei din $1948 \mathrm{nu}$ s-au oferit date explicite. In privința modului de coordonare a colaboratorilor săi, Nestor I. 1949, 116 atrăgea atenția asupra priorității "de a adânci inițierea tehnică a colectivului (...) imprimându-se totodată întregii campanii de lucru un ritm harnic, dar calm, fără goană după materiale şi după descoperiri senzaționale...".
} 
septembrie 1948 şi vara (?) lui 1949, după care aveau să fie din nou întrerupte. Dacă alegerea de către Nestor a unui sit de epocă Latène sondat anterior de Andrieșescu ar putea fi explicată ca un ecou postbelic al programului de cercetare inițiat anterior de Pârvan, motivele pentru care proiectul avea să fie abandonat subit ne rămân astăzi necunoscute.

Rezultatele celor două campanii au beneficiat de rapoarte succinte care la ora actuală oferă datele cele mai cuprinzătoare şi mai sistematizate asupra caracteristicilor vestigiilor arheologice de pe situl "Cetate". Din păcate, documentația primară a cercetărilor efectuate de Nestor (planuri, profile, însemnări ș.a.) nu a fost valorificată decât parțial în rapoarte şi astăzi pare să se fi pierdut, la fel cum s-au pierdut şi însemnările lui Andrieşescu. Date suplimentare, detaliate şi mai explicite asupra contextelor şi stratigrafiei identificate în secțiunile I-IV în 1948 şi VI-VII în 1949 (fig. 2) nu mai pot fi întregite, completate sau verificate, decât în eventualitatea fericită a regăsirii documentației întocmite sub coordonarea lui Nestor. Din această perspectivă, rapoartele publicate de Nestor sunt cu atât mai prețioase, dar în acelaşi timp, ele trebuie receptate cu precauție, fiind pasibile să conțină unele interpetări subiective, prea puțin susținute de o bază documentară consistentă: în cele două rapoarte nu au fost reproduse planuri sau profile, la fel cum nu au fost ilustrate nici materiale mai reprezentative.

Trebuie adăugat că unele date suplimentare despre stratigrafia şi vestigiile evidențiate în cele două campanii ale lui Nestor aveau să fie furnizate în 1966 de către Radu Vulpe. La ora actuală este mai greu de precizat dacă Radu Vulpe participase personal la săpăturile din 1948 (nu este menționat în colectivul din 1949!), sau dacă avusese numai posibilitatea să consulte documentația pusă la dispoziţie de Nestor ${ }^{15}$. Broşura lui Radu Vulpe

\footnotetext{
${ }^{15}$ Unele precizări surprinzător de amănunțite, cum este de exemplu cea referitoare la al treilea strat getic, "bogat în cenuşe cu reflexe violete" (Vulpe 1966, 22), sugerează o familiarizare intimă cu stratigrafia de la Zimnicea şi nu puteau fi rezultatul unor simple informări verbale. In orice caz, la data redactării broşurii sale (anterior anului 1966), Alexandrina Alexandrescu nu reluase încă cercetările de la Zimnicea. Un posibil indiciu în privința participării lui
}

avea însă caracterul unei lucrări de popularizare, iar publicarea ei a survenit la mai bine de un deceniu și jumătate după apariția rapoartelor tehnice ale lui Nestor, astfel că relevanța sa documentară trebuie percepută cu unele rezerve. După cum vom vedea în continuare, cu excepția unei interpretări particulare a modului în care s-a încheiat fiecare dintre fazele de locuire de pe "Cetate", afirmațiile lui Radu Vulpe nu contrazic concluziile lui Ion Nestor.

Problema fortificațiilor. Prin strategia sa de cercetare a aşezării, Nestor a vizat evidențierea structurilor de fortificaţie şi a stratigrafiei sitului (Nestor 1949, 116.). Patru din cele cinci sectiuni trasate în 1948 au vizat secționarea denivelării cu aspect de val din zona de nord a sitului, în încercarea de a lămuri presupusa structură a fortificațiilor. Rezultatele obținute au infirmat existența unor astfel de amenajări, astfel că Ion Nestor susținea în mod categoric faptul că "nu a existat nici un val de apărare pe această latură (latura de nord n.n.) $a<$ Cetății $>$. Toate depunerile arheologice întâlnite în acest sector se datoresc locuirii, şi anume unei locuiri foarte intense în colțul de NE al platformei" (s.n.) (Nestor 1949, 118) ${ }^{16}$. Se mai adăuga faptul că numeroasele blocuri de piatră, menționate anterior şi de Pârvan, "sunt de pus în legătură cu construcții limitate (încăperi) şi nu cu un sistem continuu de val". Denivelările din teren, interpretate anterior ca val, se dovedeau a fi rezultatul suprapunerii unor niveluri de locuire peste o "dună" naturală. Această observație avea să fie reconfirmată şi de rezultatele cercetărilor din estul sitului în 1949 (S. VI), unde porțiunea mai ridicată de teren "s'a dovedit a nu fi decât tot o vălurire naturală a terenului, la fel cu cea

Radu Vulpe la săpăturile din 1948 ar putea fi recunoscut în dedicația autografă a acestuia către Nestor pe pagina de gardă a unui exemplar al broşurii "Aşezări getice în Muntenia" aflat la biblioteca Institutului de Arheologie, din care reiese colaborarea care ar fi avut loc între cei doi la Zimnicea ("Lui Ion Nestor, în amintirea colaborării noastre de la Zimnicea. Radu Vulpe"). După cum se va vedea mai jos, acest aspect nu este lipsit de importanță.

${ }^{16}$ Informații similare la Vulpe 1966, 21 (despre absența valului), 22 ("resturi de locuințe incendiate şi refăcute fără întârziere"). 
constatată în 1948 pe latura de nord a $<$ Cetății>" (Nestor 1950, 94).

Resturile de bârne de lemn descoperite în nivelul inferior al secțiunii I, de altfel şi cea mai mică dintre secțiunile trasate (fig. 2), îi ofereau lui Nestor ocazia să sugereze existența unor "construcții puternice de lemn şi piatră", interpretate ca "palate", "turnuri", "palateturnuri" sau "locuințe întărite şi ele, ale şefilor de trib" (Nestor 1949, 118. Vulpe 1966, 22) ${ }^{17}$. Pe de altă parte, deşi observațiile din teren infirmau existența unui val de apărare, autorul săpăturilor din 1948-1949 concluziona totuşi că aşezarea getică de la Zimnicea ar fi avut fie "caracterul unui <burg> întărit de proporții restrânse" şi al unui loc de refugiu în caz de pericol, fie pe acela al unui " $<$ sat $>$ extins $-p e$ aglomerări? - dealungul malului Dunării, în preajma unei cetăți apărate (numai! - n.n.) cu şanțuri”. Trebuie remarcat însă că responsabilul cercetărilor din 1948-1949 nu a oferit nici un fel de argumente în privința caracterului antropic al "şanțurilor" care delimitează "Cetatea" şi care, de altfel, nici nu fuseseră cercetate sistematic (secționate). In schimb Nestor semnala erodarea naturală şi antropică, "lentă şi păgubitoare", a celor două şanțuri şi a malurilor abrupte care delimitează situl (Nestor 1949, 116-117) ${ }^{18}$.

Concluzia cea mai precaută ar fi presupus perceperea ansamblului de locuire preistorică de la Zimnicea ca o aşezare amplasată într-un loc mai greu accesibil şi anume pe un colț al terasei înalte de deasupra Dunării. Din păcate, autorul celor două rapoarte pare să fi învăluit o astfel de concluzie mai prudentă, dar şi mai puțin spectaculoasă, într-o suită de speculații sugerând posibile amenajări sau construcții monumentale.

\footnotetext{
17 R. Vulpe menționează în colțul de NE al aşezării "multe resturi de lemn carbonizat, indicând o mare constructie". Ecoul acestor simple afirmații ale lui Nestor şi Vulpe avea să se amplifice ulterior, determinându-1 de exemplu pe istoricul de arhitectură Curinschi Vorona G. 1981, 24 să susțină apariția în epocă getică a unei "arhitecturi aulice constând din complexe palatine identificate, unele dintre ele, cu ajutorul unor tezaure (sic) formate din arme de bronz şi podoabe de aur la Stânceşti, Zimnicea şi Albeşti”.

18 In privința eroziunii accelerate a sitului, Alexandrescu 1980, 19 efectuează la rândul ei câteva remarci semnificative.
}

Afirmațiile lui Nestor ar părea contradictorii (aşezarea nu prezintă val, dar ea ar fi totuşi "întărită"!), numai în măsura în care discursul său nu este perceput cu suficientă subtilitate. Infirmarea categorică a existenței oricăror structuri de fortificație ar fi umbrit rezultatele cercetărilor desfăşurate de un numeros colectiv, precum şi prestigiul şi spectaculozitatea sitului ales spre cercetare ${ }^{19}$. Afirmațiile aparent contradictorii ale lui Nestor au avut însă drept consecință menținerea încă pentru mult timp în istoriografie a impresiei potrivit căreia aşezarea de la Zimnicea ar fi fost fortificată (Vulpe 1966, 21) ${ }^{20}$. Ar fi trebuit reținut totuşi faptul că, pentru respingerea ipotezei lui Pârvan în privință identificării aşezării de la Zimnicea cu acea cetate getică de la nord de Dunăre pustiită de Alexandru Macedon (Arian, Anabasis I.4.4) (Pârvan 1926,

\footnotetext{
${ }^{19} \mathrm{Nu}$ trebuie trecut cu vederea faptul că cele două rapoarte ale lui Nestor fuseseră redactate în plină epocă de instaurare a regimului de democrație populară, când orice afirmație cu caracter tranșant, mai ales exprimată în scris, putea avea consecințe nefaste pentru autorul ei. Exprimarea echivocă, aparent ambiguă a ideilor şi convingerilor era una dintre măsurile de precauție curente în literatura acelei vremi. Asupra climatului intelectual al epocii, câteva repere sunt oferite de Boia 1997, 64-68.

${ }^{20}$ Radu Vulpe este printre puținii autori care au reținut observația potrivit căreia "nu s-au constatat urme de valuri"; el mai arată însă că "aşezarea este întărită printrun şanț artificial adânc". Ulterior, Radu Vulpe avea să considere că aşezarea getică de la Zimnicea este nu mai puțin decât un oppidum (Vulpe 1976, 133), cu toate că literatura antică oferă şi alți termeni mai specifici unei aşezări de mici dimensiuni (cca 1/2 ha), lipsită de fortificații, cum ar fi cea de vicus. Pentru Protase 1971, 55-56, la Zimnicea "se află cunoscuta aşezare întărită cu şanț şi val”; o afirmație similară la Vulpe A. Zimnicea, 624. Chiar şi Alexandrescu 1974a, 56 şi 1980, 43 considera că aşezarea de la Zimnicea este fortificată "printr-o vale şi printr-un şanţ" (!). De asemenea, din harta descoperirilor din secolele IV-III a.Chr. publicată de Babeş 1997, 233, fig. 9, reiese că la Zimnicea fortificatia ar fi constat dintr-un "val vitrificat". Ideea existenței unor fortificații preistorice la Zimnicea s-a propagat şi dincolo de cercul profesional al arheologilor. De exemplu, istoricul de arhitectură Curinschi Vorona G. 1981, 24 arată că "unele dintre aşezări, cum sunt Zimnicea sau Stâncești, continuă vechile cetăți hallstattiene de pământ, ale căror fortificații au fost întărite". Cititorii rapoartelor lui Nestor ar fi trebuit cel puțin să observe că acesta, precaut, a inclus în majoritatea cazurilor denumirea sitului "Cetate" între ghilimele (!), o precauţie pe care şi-a însuşit-o şi autorul acestor rânduri.
} 
46 şi 133) ${ }^{21}$, Nestor aducea în discuție tocmai evidența absenței unor fortificații (Nestor 1949, 120-121) $)^{22}$. Mai trebuie adăugat şi faptul că Nestor presupunea extinderea locuintelor preistorice şi în afara perimetrului "Cetății", o presupunere care în cazul confirmării ei ar fi anulat caracterul funcțional al fortificației cel puțin în anumite faze ale ipoteticei ei existențe (Nestor 1949, 119) ${ }^{23}$. Prin urmare, concluzia cea mai fermă care ar fi trebuit reținută este aceea a absenței unor suprastructuri de fortificatie.

Date despre stratigrafia şi cronologia aşezării. Printre câştigurile ştiințifice evidente al cercetărilor conduse de Nestor se pot număra precizarea generală a stratigrafiei din secțiunile cercetate, încadrarea cronologică mai precisă a locuirii de epocă Latène şi evidențierea locuirii medievale de pe "Cetatea" de la Zimnciea. La acestea se mai adaugă şi publicarea, în ambele rapoarte preliminare, a unor planuri generale ale sitului de la Zimnicea, în care erau indicate atât zonele cercetate, cât şi configurația terenului. Din păcate însă, din cele două rapoarte lipseşte ilustrarea profilelor descrise, o conjunctură care aruncă o umbră de incertitudine în privința afirmațiilor legate de stratigrafie.

Potrivit lui Nestor, stratigrafia sitului "Cetate" cuprindea patru niveluri de locuire de epocă Latène, suprapuse de vestigiile locuirii medievale, iar această schemă o regăsim şi în contribuția lui Radu Vulpe (Nestor 1949, 119120, Vulpe 1966, 22). Descoperirea la baza stratigrafiei, într-o "depunere nisiposloessoidă" a unui "fragment ceramic de

21. Ipoteza a fost reluată ulterior de Vulpe 1960a, 228, cu toate că "Cetatea" de la Zimnicea se află la mai puțin de o parasangă $(=5500 \mathrm{~m})$ de Dunăre, aşa cum s-ar fi plasat aşezarea cucerită de Alexandru Macedon, potrivit textului lui Arian. De fapt, "Cetatea" se află la cca 1000 m în linie dreaptă de cursul actual, regularizat prin îndiguiri moderne, al Dunării.

22 "Deşi s-ar putea argumenta că Zimnicea îndeplineşte condițiile cerute de amănuntele relatării antice, nu s-au găsit în secțiunile practicate ruine databile din sec. 4 în. d. Hr. care să justifice concluzia că aici a fost aşezarea întărită, distrusă din temelii (şi desigur incendiată) de soldații lui Alexandru". Trebuie remarcat faptul că Nestor nu menționează nimic în privința unor distrugeri provocate prin incendiu, aşa cum aveau să facă Vulpe 1966, 22 şi mai ales Alexandrescu 1974a, 56.

23 "... locuințele acestei populații vor trebui cercetate în regiunea din jurul cetății ...”. O sugestie similară avea să fie oferită şi de Alexandrescu 1974a, 56. fabricație grecească, probabil atică, din specia vaselor pictate cu figuri roşii, datat pe la sfârşitul sec. 5 în.d.Hr.", oferea un indiciu consistent pentru încadrarea cronologică a începutului locuirii de pe "Cetate" (Nestor $1949,119)^{24}$. De asemenea, Nestor, şi ulterior Radu Vulpe, menționau şi suprapunerea şi deranjarea de către cel mai vechi nivel de locuire de epocă timpurie Latène a unor morminte hallstattiene (Nestor 1949, 119) ${ }^{25}$.

Pentru încadrarea cronologică a nivelului superior de epocă târzie Latène, Nestor se mulțumea să menționseze identificarea la baza acestuia a unui context din care provenea o monedă autonomă a orașului Odessos de la sfârșitul secolului al II-lea a.Chr. (Nestor 1950, 94-95 $)^{26}$. Prin urmare, Nestor considera că "ultimul strat consistent de locuire Latène de la Zimnicea este anterior epocii Burebista". Astfel, Nestor era în măsură să stabilească limitele cronologice ale perioadei de locuire intensă ${ }^{27}$ de la Zimnicea între secolele al IV-lea şi al II-lea a.Chr. De asemenea, Nestor menționa şi identificarea unor "rare indicii, dar certe, ale unei uşoare locuiri şi dintr-o epocă ulterioară, anume din sec. 1 e.n.”, fără să ofere însă alte detalii. Deşi sumare, aceste observații infirmau şi nu "demonstrau hotărât întreruperea bruscă" a locuirii getice de la Zimnicea în contextul acțiunilor lui Aelius Catus (Strabo VII.3.10.), aşa cum aveau să considere mai târziu Constantin Daicoviciu sau Radu Vulpe, şi aşa cum avea să sugereze chiar şi Alexandrina Alexandrescu (Daicoviciu 1960, 290; Vulpe 1960b, 518; Vulpe 1960c, 317-318; Alexandrescu 1974a, 57) ${ }^{28}$.

\footnotetext{
${ }^{24}$ Fragentul, menționat şi de Vulpe 1966, 22, nu a fost din păcate ilustrat.

${ }^{25}$ In privința mormintelor hallstattiene de pe "Cetate", Vulpe 1966, 22 arată că "înainte de înființarea aşezării getice, terenul fusese folosit peste tot (s.n.) ca cimitir".

${ }^{26}$ Moneda, descoperită în secțiunea VII, avea să fie ulterior descrisă și ilustrată de Mitrea 1965, 252-253, nr. 13 , fig. $1 / 5$.

${ }^{27}$ In privința caracterului intensiv al locuirii trebuie reținută informația suplimentară furnizată de Vulpe 1966, 23, potrivit căreia, "răscolirile şi nivelările produse de așezările care s-au succedat, n-au putut lăsa urmele complete ale unui atare plan (de locuințe ? n.n.). Până acum, resturile de locuințe n-au fost găsite decât în dezordine".

${ }^{28}$ Datarea propusă de Nestor a fost de altfel respinsă explicit de către Vulpe 1966, 23 şi 1976, 133, n. 46.
} 
In aceleaşi rapoarte se mai preciza că vestigiile locuirii medievale de pe "Cetate" şi din împrejurimi ar fi aparținut unui "mic cătun de bordee", datat cu prudență în secolele XIII$\mathrm{XV}$, care a suprapus şi parțial au deranjat nivelurile anterioare de locuire ${ }^{29}$.

Alte informații legate de materialele şi elementele de datare ale nivelurilor superioare ale aşezării preistorice de la Zimnicea nu au mai fost furnizate în cele două rapoarte ale lui Nestor. Unele indicii cronologice prețioase aveau să fie completate ulterior de Irina CasanFranga. Indrumată de către Nestor (CasanFranga 1967, 16, nt. 13), ea publica, în 1967, mai multe fragmente de cupe cu decor în relief locale şi două fragmente de cupe hemisferice de sticlă de import descoperite în campaniile 19481949 la Zimnicea, cu mențiunea că acestea provin din cele două niveluri superioare ${ }^{30}$.

In ciuda unei mai bune sistematizări a informațiilor decât mențiunile disparate ale lui Pârvan, expunerea lui Nestor, fie şi îmbogăţită prin câteva informații suplimentare oferite de Radu Vulpe, nu are decât un caracter preliminar şi cu totul general, este lipsită de date tehnice sau de ilustrarea materialelor reprezentative descoperite. $\mathrm{Nu}$ poate fi trecut cu vederea faptul că în Getica lui Pârvan se menționaseră în mod explicit mai multe materiale din aşezare (mai ales indicatori cronologici, precum amforele rhodiene, importuri attice sau cupe "deliene"), decât în ambele rapoarte semnate de Ion Nestor $^{31}$. Aceste neajunsuri nu se datorează

\footnotetext{
29 Potrivit unor reprezentanţi ai istoriografiei dedicate arheologiei Evului Mediu românesc, prin inițierea de către Nestor a cercetării locuirii medievale la Zimnicea, se puneau "bazele unei metode ştiințifice de cercetare arheologică şi în domeniul arheologiei feudale" (Zaharia 1967, 9) şi se inaugurau "începuturile propriuzise ale cercetărilor arhelogice întreprinse în aşezările rurale medievale" (Matei 1979, 412). Din păcate, continuatorii programului inițiat de Ion Nestor nu aveau să fructifice în vreun fel materialele medievale descoperite pe "Cetate".

${ }^{30}$ Despre cele două fragmente de cupe de sticlă de import: Casan-Franga 1967, 14, 18, nt. 18, 17, fig. 6/29; pentru cele 17 fragmente de cupe locale cu decor in relief ("deliene getice"): Casan-Franga 1967, fig. 5/5, 7/1-4, 8/1-8; 11/1-4.

${ }^{31} \mathrm{Cu}$ excepția fragmentului attic cu figuri roşii şi a monedei de la Odessos, Nestor 1949, 118 se mulțumea să menționeze doar în treacăt descoperirea altor materiale reprezentative, "monete, fibule, ceramică grecească de import şi indigenă de calitate superioară",
}

unor "neglijențe" ale autorului, ci trebuie percepute din perspectiva concepției lui Nestor asupra unei abordări etapizate a valorificării rezultatelor cercetărilor arheologice, publicarea unor rapoarte generale constituind numai preliminariile realizării unor studii particulare. Trebuie precizat că cele două rapoarte semnate de Nestor vizau prezentarea generală a rezultatelor săpăturilor, semnalarea potențialului arheologic al sitului şi anunțau inaugurarea unui program de cercetare aprofundată, care avea să dea rezultate concrete (din păcate numai în privința ansamblurilor funerare) de-abia trei decenii mai târziu ${ }^{32}$.

La ora actuală, motivele pentru care Nestor nu a continuat cercetările de la Zimnicea rămân obscure. Pe de o parte, putem bănui că acesta se considera edificat în privința potențialului sitului. Pe de altă parte, se poate presupune că reluarea de către Alexandrina Alexandrescu în 1966 a cercetărilor de la Zimnicea, participantă la campaniile din 19481949, era rezultatul nemijlocit al sugestiilor şi recomandărilor lui Nestor, asigurându-se astfel "predarea ştafetei" între generații şi continuitatea demersului ştiințific. Tot în acest sens, trebuie reamintit şi faptul că Nestor pusese la dispoziția Irinei Casan-Franga fragmentele de cupe cu decor în relief descoperite pe "Cetate" (In acest sens CasanFranga 1967, 16, n. 3; Vulpe, Gheorghiță 1976, $168)^{33}$, lui Bucur Mitrea monedele identificate sau achiziționate în cursul celor două campanii (Mitrea 1965, 239-247) $^{34}$, lui Dumitru Tudor

fără să ofere detalii suplimentare. Numai Vulpe 1966, 23 mai menționează apartenența la inventarul aşezării, "într-o proporţie covârşitoare", a unor fibule tracice de bronz şi argint, dar se poate pune întrebarea dacă această referire nu vizează de fapt descoperirile din necropolă.

${ }^{32}$ După cum arăta chiar Nestor 1950, 94 "un mare număr de detalii semnificative vor putea fi comunicate deabia după o prelucrare atentă a materialului recoltat şi o raportare minuțioasă a lui la nivelele arheologice constatate". Dezideratele stabilite de Nestor pentru cercetarea de la Zimnicea (în acest sens vezi şi Nestor 1950, 94-96) aveau să fie înfăptuite în bună măsură (dar din păcate numai pentru materialele rezultate din cercetarea necropolelor) de către A. D. Alexandrescu, prin studiile sale publicate în anii ' 70 şi ' 80 .

${ }^{33}$ In acest sens Casan-Franga 1967, 16, n. 3 şi Vulpe, Gheorghiță 1976, 168.

34 Trebuie precizat că dintre cele 33 de monede provenind de la Zimnicea, numai o monedă de la 
amforele ştampilate de import şi alte câteva fragmente ceramice locale cu ștampile anepigrafice (Tudor 1967, 42, n. 36) ${ }^{35}$, iar lui Radu Vulpe îi oferise, după toate aparențele, documentația de şantier. Contribuțiile tuturor acestor colaboratori sau colegi de breaslă aveau să fie publicate în acelaşi perioadă (1965-1967) în care Alexandrina Alexandrescu relua săpăturile pe "Cetate" şi "Câmpul morților". Acest sincronism care sugerează că preocuparea lui Nestor pentru aşezarea preistorică de la Zimnciea nu se estompase, ci prin intermediul colaboratorilor săi mai tineri el asigura continuarea proiectului de cercetare inițiat în 1948.

\section{Rezultatele cercetărilor Alexandrinei Alexandrescu în anii 1966-1975}

Dacă în privința valorificării sistematice a necropolelor (din epoca bronzului, hallstattiană şi Latène) rezultatele cercetărilor coordonate de Alexandrina Alexandrescu sunt meritorii, dacă nu chiar exemplare (Alexandrescu 1972, 1973, 1974b, 1978, 1980 şi 1983), datele publicate referitoare la aşezare sunt cu totul lacunare, în ciuda cercetării sistematice a mai multor suprafețe de pe "Cetate". Expresivitatea inventarelor funerare şi multiplele lor valențe interpretative, facilitatea identificării, ordonării şi clasificării lor, şi nu în ultimul rând, abundența indicatorilor cronologici contrastau cu dificultățile perceperii şi înregistrării situațiilor stratigrafice din aşezare care, din perspectiva cercetărilor recente, s-au dovedit a fi extrem de complexe.

Odessos (nr. 13) a fost identificată în mod cert în urma cercetărilor sistematice pe "Cetate". Alte monede, provin din cercetările contextelor funerare sau din descoperiri întâmplătoare realizate pe "Cetate" şi care au fost achiziționate de Nestor de la localnici. După cum remarcă Bucur Mitrea, spectrul cronologic ilustrat de monedele identificate întâmplător sau prin cercetări sistematice pe Cetate confirmă încadrarea cronologică propusă de Nestor pentru perioadele de locuire preistorică şi medievală de aici.

${ }^{35}$ Dumitru Tudor dispunea nu numai de cele câteva ştampile amforice greceşti provenind din săpăturile lui Nestor (şase exemplare: Tudor 1967, 70-73, nr. 125 , $129,130,136,137,139)$, ci şi de cele identificate în 1924 (nouă exemplare), la care probabil făcuse anterior referire şi Pârvan. Din păcate, informații referitoare la contextul arheologic al acestor importuri nu a fost consemnat.
La cele şapte secțiuni cercetare anterior (unele integral, altele parțial) de Nestor, A.D. Alexandrescu a mai efectuat încă 12 , numerotate în continuarea celor efectuate de predecesorul ei şi amplasate în diferite zone ale sitului (fig. 2): în zona înaltă din nord-est (S. VIII, XII, XIII-XV, XVII), şi în sud-est (S. IXXI), în colţul de nord-vest (S. XVI şi XVIa), precum şi în zona centrală a sitului (S.XVIII) ${ }^{36}$. Din păcate, documentația întocmită de Alexandrina Alexandrescu în cursul cercetărilor din aşezare nu a mai fost valorificată şi s-a pierdut, astfel că despre contextele arheologice şi materialele descoperite în numeroasele suprafețe cercetate nu s-au păstrat informații consistente.

Observații stratigrafice şi remarci asupra evoluției aşezării. In 1974, Alexandra Alexandrescu publica un scurt articol în care prezenta sintetic şi succint problematica evidențiată de cercetările de la Zimnicea în ansamblul lor. Dacă majoritatea considerațiilor vizau ansamblurile funerare, prezentarea aşezării getice se întinde pe mai puțin de două pagini şi conține singura intervenție edită dedicată stratigrafiei "Cetății”, semnată de către Alexandrina Alexandrescu (Alexandrescu 1974a, 47-64; despre aşezarea preistorică de pe "Cetate": $56-58)^{37}$. Spre deosebire de schema stratigrafică prezentată de Nestor, reprodusă apoi de Radu Vulpe, şi care cuprindea numai patru niveluri de locuire, Alexandrina Alexandrescu distingea cinci, fiecare dintre ele fiind sigilat de câte un incendiu (denumit şi calamitate sau cataclism) (Alexandrescu 1974a, 56-57 şi 1976, 136). Fără să i se ofere vreun argument cronologic consistent, cititorul contribuției din 1974 are surpriza să afle că fiecare incendiu corespunde câte unui eveniment de răsunet care, potrivit surselor literare, ar fi marcat istoria regiunii Dunării de Jos în ultimele patru secole a.Chr.: primul incendiu este legat de trecerea Dunării de către Alexandru cel Mare, cel de al II-lea de conflictul Lysimachos-Dromichaites, un al IIIlea incendiu ar fi survenit în secolul al II-lea

\footnotetext{
${ }^{36}$ V. anexa de la sfârşitul acestei contribuții.

${ }^{37}$ Un rezumat românesc al considerațiilor referitoare la aşezarea de la Zimnicea din această contribuție mai puțin cunoscută a Alexandrinei Alexandrescu a fost oferit de Babeş 2001, 507-508.
} 
a.Chr., cel de al IV-lea incendiu era atribuit, ce e drept, cu unele rețineri, lui Burebista, iar sfârșitul locuirii getice ar fi avut loc odată cu transferarea populației locale la sud de Dunăre la începutul secolului I p.Chr. ${ }^{38}$.

Totuşi, între schema pentapartită (Alexandrescu) şi cea quadripartită (Nestor) se poate realiza o corelare, pe baza informației lui Radu Vulpe, potrivit căreia nivelul getic inferior determinat în campaniile 1948-1949 ar ilustra în două faze, sugerate de acele "resturi de locuințe incendiate în două rânduri (s.n.) şi refăcute fără întârziere" (Vulpe 1966, 22). Din această perspectivă, trebuie remarcat rolul semnificativ al contribuției lui Vulpe care oferă posibilitatea armonizării celor două scheme stratigrafice, precum şi aportul din păcate lipsit de noutate al Alexandrinei Alexandrescu în aprofundarea stratigrafiei aşezării getice. $\mathrm{Nu}$ trebuie însă pierdut din vedere faptul că anterior contributiiilor Alexandrinei Alexandrescu, ideea sigilării fiecăruia dintre nivelurile de locuire de la Zimnicea prin câte un incendiu fusese introdusă în dezbaterea științifică de către Radu Vulpe (Vulpe 1966, 22) ${ }^{39}$, cu toate că în mod straniu, Ion Nestor nu făcuse nici o referire în acest sens. Corelarea incendiilor cu evenimentele amintite constituie însă contribuția

\footnotetext{
${ }^{38}$ Deşi autoarea nu o afirmă explicit, putem bănui că prin "transferarea" de populație se făcea referire la pasajul din Strabo VII.3.10 în care este relatată acțiunea întreprinsă de Sextus Aelius Catus de strămutare a unor comunități nord-dunărene la sud de fluviu (probabil în 2-3 p.Chr., potrivit lui Syme R. 1971, 55). După cum arată şi Vulpe R. 1960c, 318, ideea explicării încheierii locuirii mai multor aşezări din Câmpia Română la începutul secolului I p.Chr. prin acțiunile lui Aelis Catus, a fost inițial sugerată, "ca o deducție logică", de către Pârvan 1926, 128-130 (!). Potrivit lui Radu Vulpe, această "deducție logică" - de fapt o ipoteză tentantă -, ar fi fost "excelent confirmată de constatările arheologice" (s.n.) efectuate printre altele şi la Zimnicea, unde aşezarea ar fi încetat "evident (s.n.), ca rezultat al depopulărilor lui Aelius Catus". Din păcate, stadiul publicării materialelor descoperite la Zimnicea nu era pe atunci, la fel cum nu este nici acum în măsură să infirme, dar nici să susțină o astfel de teorie, care, iată, a făcut carieră în scrierile mai multor generații de istorici şi arheologi. Tocmai din acest motiv, mai târziu Radu Vulpe avea să respingă încadrarea cronologică sugerată de Nestor.

39 "Incendiile cu care s-au sfârşit toate (s.n.) aşezările succesive reprezentate de diferite straturi se explică uşor dacă ne gândim că locuințele erau aglomerate şi construite din material inflamabil".
}

originală a Alexandrinei Alexandrescu şi oglindește efortul de ancorare în "istoric" a sitului cercetat.

In mod evident, o asemenea interpretare a stratigrafiei era rezultatul însuşirii temeinice a informațiilor furnizate de sursele literare, dar şi al aplicării lor paradigmatice pe o evidență arheologică prea puțin documentată sau poate prea puțin expresivă. Se poate bănui că perspectiva romantică despre o locuire getică, ce renăştea după fiecare dezastru "din propria-i cenuşă" (Alexandrescu 1974a, 57) ${ }^{40}$, îşi găseşte sorgintea în împletirea dintre concepția determinismului istoric al obiectului arheologic şi mitul atât de viu în istoriografia românească al continuității populației autohtone (In acest sens Boia 1997, 133-144, şi mai ales 140$)^{41} . \mathrm{Cu}$ riscul de a mă repeta, țin să sublineiz că în cele câteva considerații dedicate de Alexandrina Alexandrescu "Cetății” de la Zimnicea în contribuția sa din 1974 nu este menționat nici măcar un singur element de datare raportat la stratigrafie, care să îi susțină suita de afirmații istoricizante.

$\mathrm{Cu}$ toate acestea, dintr-unele considerații disparate, publicate separat (nu în contribuția din 1974), se poate deduce faptul că în cursul săpăturilor desfăşurate în aşezare, succesoarea lui Nestor acordase o atenție deosebită repartitiei stratigrafice a diferitelor forme ceramice, în vederea evidențierii evoluției şi transformărilor repertoriului morfologic de-a lungul celor patru secole de existență a aşezării getice. Putem bănui că interesul pentru evidențierea unor fortificații fusese diminuat, dacă nu spulberat, de rezultatele cercetărilor mai vechi. Potrivit Alexandrinei Alexandrescu, aşezarea getică de la Zimnicea s-ar fi delimitat "printr-o vale şi printr-un şanț" (Alexandrescu 1974a, 56) ${ }^{42}$ numai la sfârşitul secolului al IV-

\footnotetext{
${ }^{40}$ A. D. Alexandrescu arăta explicit despre aşezare că "elle renaîtra de ses cendres".

41 "Cum sursele literare sunt în general epuizate, istoriografia românească a mizat pe arheologie. Problema continuității a devenit astfel aproape o problemă exclusiv arheologică”.

42 "L'agglomération était fortifiée d'une vallée et d'une fossé" (!). In mod straniu, autoarea nu sesiza că o fortificație care constă dintr-o "vale" nu este o fortificație, ci o formă de relief de care comunitățiile preistorice vor fi profitat, desigur, pentru a-şi instala locuinţele într-un loc ferit, mai greu accesibil. In
} 
lea şi la începutul secolului al III-lea a.Chr., perioadă după care locuirea s-ar fi extins probabil şi în zona denumită prin tradiție "Câmpul morților".

Implicată în valorificarea sistematică şi publicarea contextelor funerare de epocă Latène de la Zimnicea, Alexandrina Alexandrescu a sugerat unele paralelisme între stratigrafia din secțiunile cercetate în aşezare şi mormintele târzii cu fibule de schemă Latène $\mathrm{B}$ şi $\mathrm{C}$ în inventar: se atrăgea atenția asupra analogiilor dintre formele ceramice provenind din inventarele acestor morminte şi cele identificate în nivelul IV al aşezării (Alexandrescu 1972, $17)^{43}$. Se poate pune întrebarea dacă în materialele identificate în acest nivel s-ar putea întrevedea aceiaşi "modificare a trăsăturilor la unele forme de vase vechi, iar pe de altă parte apariția unor forme noi care nu pot fi socotite dezvoltări ale unor forme locale" observată în cazul ceramicii din necropolă (Alexandrescu 1972, 17). In orice caz, potrivit responsabilei cercetărilor din anii ' 70 , diminuarea înmormântărilor şi sărăcirea inventarului contextelor funerare din secolul al II-lea a.Chr. şi de la începutul secolului următor ar corespunde în mod surprinzător, tocmai cu faza de dezvoltare maximă a aşezării de la Zimnicea (Alexandrescu 1974a, 62). Din păcate, aşa cum necropola "se întinde pe un spațiu foarte mare care nu a fost delimitat" (Alexandrescu 1972, 19), nici pentru locuirea din această perioadă mai târzie nu dispunem de indiciile concrete ale extinderii ei maxime (probabil dincolo de "valea" şi "şanțul" care delimitează "Cetatea").

Singura formă ceramică pentru care se face o referire explicită şi care ar exprima

privința caracterului antropic al şanțului, nici de această dată nu se aduc suficiente argumente. In ultimă instanță, se poate considera că existență unui şanț, fie el artificial, nu constituie decât o formă de delimitare a unei aşezări, nicidecum o fortificație concretă cu fundații şi elevație.

43 "Datarea mormintelor (târzii - n.n.) de la Zimnicea se bazează pe ceramică şi fibule. Pentru ceramică, în special, pe lânga analogiile ce se pot face cu alte necropole sau aşezari, cel de al IV-lea nivel din aşezarea de la Zimnicea a oferit cele mai bune paralele". In acelaşi sens, Alexandrescu 1974a, 63: "Les meilleurs analogies de la céramique meublant les tombes de cette époque sont fournies par les grandes agglomérations daces du pays, celle de Zimnicea (horizont 4) en tout premier lieu". continuitatea unei tradiții îndelungate în producția ceramică locală este oala cu brâu, despre care se afirmă că se regăseşte atât în morminte din secolul al III-lea a.Chr., cât şi în nivelul superior din aşezare (Alexandrescu 1980, 45). Aceste observații pasagere şi, din păcate, prea puțin convingătoare, ar fi trebuit susținute prin sistematizarea unei documentații extrem de complexe şi prin desfăşurarea unui sistem argumentativ concludent, sintetizat întrun studiu particular dedicat ceramicii din aşezare. Un astfel de demers nu a fost realizat.

Constatările edite ale Alexandrinei Alexandrescu, completate probabil şi cu unele informații verbale mai explicite, aveau să fie reproduse de Emil Moscalu care arăta că "nivelele I, II şi III ale cetăţii de la Zimnicea aparțin aspectului Canlia, iar nivelul IV şi mormintele cele mai târzii ale necropolei aparțin unei faze de tranziție între aspectul Canlia şi cultura Sarmizegetusa (...). Aici ceramica fazei a III-a a Latène-ului geto-dacic aparține numai în prima jumătate a sec. II î.e.n. şi unul din elementele specifice ale acestei faze este cățuia.” (Moscalu 1983, 192-193) . $^{44}$. Afirmația nu îndeajuns de explicită a lui Moscalu în privința prezenței la Zimnicea a unei (unor?) cățui constituia o noutate. Pe de altă parte, trebuie remarcat şi faptul că Moscalu reținuse schema stratigrafică quadripartită propusă de Nestor în 1949 şi nu pe cea pentapartită propusă de Alexandrina Alexandrescu în 1974.

Prin urmare, față de concluziile lui Nestor din 1949-1950, cele câteva referiri publicate ale cercetărilor anilor ' 70 -' $80 \mathrm{nu}$ au adus modificări flagrante schemei stratigrafice a aşezării Latène de la Zimnicea, ci doar au adăugat unele nuanțări, prea puțin semnificative şi prea sumar argumentate, în privința încadrării cronologice a celor patru (eventual cinci?) niveluri de locuire. La aceasta se mai adaugă câteva materiale descoperite în aşezare şi publicate disparat, care contribuie într-o măsură

\footnotetext{
${ }^{44}$ Este posibil ca Moscalu să fi beneficiat de informații verbale oferite de responsabila cercetărilor de la Zimnicea sau poate chiar să fi avut acces direct la materiale descoperite aici. Valabilitatea afirmației privind prezența unor cățui în contextele de locuire getică de la Zimnicea a fost verificată în săpăturile recente.
} 
modestă la completarea parțială a lacunelor de informație.

Materiale reprezentative şi indicatori cronologici. Urmând unul dintre îndemnurile mai vechi ale lui Nestor (Nestor 1950, 100) ${ }^{45}$, Alexandrina Alexandrescu realiza în 1976 un articol dedicat fibulelor tracice descoperite la Zimnicea. In mod surprinzător, cercetările desfăşurare în aşezare nu furnizaseră decât o singură fibulă de tip tracic, restul de exemplare ale acestei categorii de obiecte provenind din contexte funerare. Potrivit mentiunilor Alexandrinei Alexandrescu, fibula respectivă a fost descoperită în campania din 1968, în $S$ XIV, în umplutura unei gropi a cărei apartenență la nivelurile I sau II ale aşezării nu a putut fi elucidată (Alexandrescu 1976, 133) ${ }^{46}$. In acelaşi studiu, Alexandrina Alexandrescu ilustra prin desen şi un fragment de capac care păstra urma imprimată în pasta moale a unei fibule tracice şi care fusese descoperit în campania 1948 în nivelul al III-lea de locuire

\footnotetext{
${ }^{45}$ Ion Nestor recomanda, ca urmare a cercetărilor de la Zimnicea, studierea evoluției fibulelor de tip tracic şi aprofundarea relațiilor supraregionale "dintre masa geto-dacică de la nord de Dunăre şi din podişul ardelean şi masa tracică din Peninsula Balcanică”. Probabil, descoperirile de fibule tracice din mormintele de la Zimnicea, dar şi fragmentul de capac cu urma imprimată a unei astfel de fibule, descoperit în S. IV/1948, publicat mult mai târziu (Alexandrescu 1976, 134, fig. 2/15), oferiseră indiciile necesare pentru o revizuire a încadrării cronologice a acestei forme de fibulă. In stadiul incipient al cercetării de până atunci, datarea fibulelor tracice era plasată în perioada Lateneului târziu dacic (Nestor 1933, 158-160). Cu alte cuvinte, cercetările de la Zimnicea au avut menirea de a trezi interesul pentru o epocă prea puțin precizată până atunci şi anume aceea a Latène-ului timpuriu "getic" de la Dunărea de Jos.

46 "De toutes les pièces trouvées à Zimnicea, un exemplaire a été mis au jour dans une fosse de l'agglomération, dont on ne saurait dire si elle appartient au premier ou au deuxième horizon..."; p. 136: "Une fibule mise au jour dans l'agglomération appartient à la variante IIIc. Son arc est décoré, il est applati de même que le pied, assez long. Trouvée dans un dépôt qu'on ne saurait attribuer au premier ou au deuxième horizont, cette fibule a subi une forte déformation par suite d'un incendie...". De asemenea, în la p. 134, în fig. 2/13 (nu în text !) se indica anul în care a fost descoperită fibula (campania din 1968), precum şi secțiunea din aşezare unde a fost descoperită această piesă (S. XIV). Nu se oferă alte date legate de contextul de descoperire.
}

Latène (încadrat în secolul al III-lea a.Chr.) (Alexandrescu 1976, 134, fig. 2/15, 135-136) ${ }^{47}$.

Importanța acestor două descoperiri nu a fost îndeajuns exploatată în lămurirea cronologiei nivelurilor aşezării de la Zimnicea (decât indirect, în considerațiile lui Moscalu, menționate mai sus). Contextele în care au fost descoperite cele două piese ar fi permis întrevederea unei sincronizări între perioada de folosire a fibulei tracice şi nivelurile inferioare de locuire (I-III) din aşezarea de la Zimnicea, spre deosebire de nivelul superior (IV) din care, după toate probabilitățile, proveneau cupele cu decor în relief menționate de Pârvan sau cele publicate de Irina Casan-Franga, cățuia menționată de Moscalu sau acel context amintit de Nestor care se data pe baza unei emisiuni autonome a cetății Odessos. In acest sens erau, de altfel, relevante analogiile formelor ceramice din mormintele cu fibule de schemă Latène $\mathrm{C}$ şi din nivelul IV de locuire al aşezării. In mod straniu, Alexandrina Alexandrescu nu a făcut nici o referire la prezența la Zimnicea a cupelor cu decor în relief, cu toate că în studiul lor din 1976, Alexandru Vulpe şi Marieta Gheorghiță dispuneau de o serie de informații noi (în raport $\mathrm{cu}$ studiul Irinei Casan-Franga) asupra fragmentelor aparținând acestei specii de recipiente de băut descoperite în aşezarea getică de pe "Cetate" (Vulpe, Gheorghiță 1976) ${ }^{48}$. In concluzie, se poate considera că rezultatele cercetărilor Alexandrinei Alexandrescu în aşezarea de la Zimnicea au fost inserate în literatura de specialitate, cu prea multă reținere, dacă nu cu zgârcenie, şi cu prea puțin suport documentar.

\footnotetext{
47 "Un fragment de couvercle orné de l'impression d'une fibule de ce genre (fig. 2/15), mis au jour dans le troisième horizon de l'habitat développé après le deuxième cataclysme qui détruisit complètement le site vers les années 300". Fragmentul ceramic mai fusese anterior ilustrat prin fotografie de Vulpe 1966, fig. 7 (dreapta).

${ }^{48}$ Trebuie precizat că față de cele numai 17 fragmente de cupe locale cu decor în relief, ilustrate și comentate de Irina Casan-Franga în 1967, aproape un deceniu mai târziu Alexandru Vulpe şi Marieta Gheorghiță menționau ca provenind de la Zimnicea, fie 37 de fragmente (în fig. 3, p. 178), fie 50 de astfel de piese (în text la p. 179). Probabil, cei doi autori erau la curent cu materialele rezultate din cercetările Alexandrinei Alexandrescu, însă în absența unei documentații şi a unor infirmații mai detaliate, afirmațiile lor oscilante trebuie acceptate cu oarecare reținere.
} 
Sistarea cercetărilor de la Zimnicea. Sistarea cercetărilor de la Zimnicea în 1975, datorată retragerii din viața științifică a Alexandrinei Alexandrescu (Marinescu-Bîlcu 1997, 13), a survenit într-un context nefast pentru tradiția științifică-arheologică românească. Perioada care a urmat a fost marcată de consecințele nefaste ale dispariției unor personalități de marcă, formate în perioada interbelică, aşa cum a fost cazul lui Nestor, dar şi de deprecierea progresivă a politicii culturale promovate de regimul totalitar românesc. In condițiile diminuării susținerii financiare a cercetării, dar mai ales în contextul înghețării în anii ' 80 a mecanismelor de promovare profesională, continuatorii proiectelor de cercetare inițiate de Ion Nestor nu au mai avut posibilitatea de a-şi forma la rândul lor succesori ştiințifici. Preocuparea pentru armonizarea interesului mai multor specialişti în colective de cercetare concentrate asupra unor obiective bine determinate s-a estompat, iar cercetarea arheologică s-a atomizat. In această conjunctură, nu numai că cercetările de teren de la Zimnicea au fost abandonate, dar şi materialele şi informațiile dobândite în vechile săpături au rămas neprelucrate şi nevalorificate. Pentru un sfert de secol, vestigiile getice ale aşezării de la Zimnicea aveau să fie lăsate iarăşi pradă uitării.

\section{Concluzii. Sintetizarea informațiilor publicate despre aşezarea de epocă Latène de la Zimnicea}

Date generale despre situl "Cetate", evidențiate în cercetarea mai veche. In ciuda modului disparat de prezentare în literatura de specialitate a informațiilor despre situl "Cetate" de la Zimnicea, la ora actuală se poate totuşi contura, fie şi numai pe baza datelor publicate, o imagine generală a caracteristicilor arheologice ale acestui obiectiv care a atras atenția atâtor generații de arheologi. Rezultatele publicate ale cercetărilor de până acum au evidențiat că în punctul "Cetate" se regăsesc vestigii din trei epoci distincte şi anume morminte hallstattiene deranjate de o locuire intensă care a continuat pe aproape întreaga durată a epocii Latène, care la rândul ei a fost suprapusă de o locuire medievală cu caracter rural din secolele al XIV-lea şi al XV-lea. De asemenea, stratigrafia sitului pare a fi extrem de complexă, desfăşurându-se pe alocuri până la 4 $m$ adâncime.

Deși morfologia terenului pare să fi sugerat din totdeauna localnicilor, dar şi arheologilor existența unor întărituri, așezarea de epocă Latène de pe "Cetate" nu pare să fi fost prevăzută cu fortificații concrete, zidite din piatră fasonată sau nu, clădite din cărămizi (fie ele arse, fie ele crude, după cum consideră fiecare dintre părțile implicate în disputa asupra incintei de la Coțofenii din $\operatorname{Dos}^{49}$ ), sau constituite din şenaje de lemn şi aglomerări de bolovani şi pământ bătut (aşa cum se întâmplă în cazul fortificatiiilor de tip murus gallicus ${ }^{50}$ ) ş.a. Vestigii ale unor astfel de sisteme constructive cu caracter defensiv nu au fost niciodată menționate în literatura dedicată "Cetății" de la Zimnicea, în ciuda cercetărilor îndelungate desfăşurate aici.

In privința acelor denivelări din teren interpretate ca şanțuri, cercetarea de până acum nu a oferit argumente suficiente în privința caracterului lor antropic. In schimb, s-au oferit unele indicii în privința extinderii locuirii de epocă Latène şi dincolo de aceste aşa numite "şanțuri", care s-ar putea dovedi a fi nişte simple făgaşe constituite sub acțiunea factorilor de eroziune naturală (poate şi antropicămodernă?) exercitați asupra solului local de loes din care este alcătuită terasa înaltă aflată deasupra luncii Dunării. Considerarea aşezării getice de la Zimnicea ca "fortificată natural", o expresie eufemistică, înzestrată chiar cu un oarecare iz poetic, dar pe cât de încetățenită în literatura arheologică românească, pe atât de confuză, nu ar avea decât darul de a disimula absența unei documentații explicite.

Cercetările mai vechi nu au lămurit nici caracteristicile acelor construcții sau amenajări din lemn şi piatră, de dimesiuni mai mari

\footnotetext{
49 Asupra fortificației de la Coțofenii din Dos, şi mai ales asupra modului de prelucrare a cărămizilor de acolo, Zirra et alii 1993 şi opiniile contrare ale lui Babeş 1997.

50 Din vasta literatură vest- şi central-europeană dedicată fortificatiilor de tip murus gallicus, nu voi aminti decât consistenta contribuție a lui Endert D. v. 1987 şi succinta sinteză a lui Meylan F., Murus Gallicus (ambii cu literatura mai veche). Pentru explicarea conținutului noțiunii de "val vitrificat", Babeş 1997, 230-231, n. 85
} 
(neprecizate, dar care îl determinau pe Nestor să vorbească despre "turnuri" sau "palate"), ale căror resturi au fost identificate numai în S I şi S II. Potrivit indiciilor furnizate în literatură (atât de Pârvan cât şi de Nestor), pentru ridicarea amenajărilor identificate în interiorul aşezării de epocă Latène, s-au folosit bârne de lemn, bolovani pentru fundații şi eventual stuf (chirpiciul sau vălătucii nu sunt menționați). Pasager, Alexandrina Alexandrescu menționează şi folosirea țiglelor pentru acoperişuri într-o perioadă anterioară lui Burebista (probabil în prima jumătate a secolului I a.Chr., ceea ce ar corespunde nivelului IV din aşezare), o afirmație mai degrabă suspectă decât credibilă (Alexandrescu 1974a, 56).

Stratigrafia aşezării de epocă Latène a fost interpretată istoricizant de către Alexandrina Alexandrescu, dar descrisă mai tehnic şi mai detaliat de către Ion Nestor şi Radu Vulpe şi din acest motiv, consider că ar trebui reținute mai degrabă considerațiile acestora din urmă. In schema propusă de Nestor, stratigrafia "Cetății" cuprinde patru niveluri de locuire, dintre care cele trei inferioare conțin elemente de datare din secolele IV-III a.Chr. şi anume: ceramică grecească (attică) de lux, amfore ştampilate, o fibulă tracică şi un fragment de capac cu impresiunea unei astfel de fibule în pasta moale.

Nivelul superior (IV) pare să conțină elemente de datare care în cercetarea actuală sunt considerate ca indicatori cronologici specifici sfârşitului secolului al II-lea şi primei jumătăți a secolului I a.Chr., aşa cum sunt imitaţiile locale de cupe deliene şi suprapune acel context din care provine emisiunea autonomă a cetăţii Odessos, datată la sfârşitul secolului al II-lea a.Chr.

La toate acestea mai trebuie adăugate analogiile invocate (dar niciodată prezentate sistematic şi detaliat sau ilustrate) dintre piesele ceramice din inventarele funerare în care se regăsesc fibule de schemă Latène şi formele ceramice identificate în aşezare. De altfel, raportul de 3/1 dintre numărul nivelurilor de locuire mai vechi şi mai noi din schema propusă de Nestor, pare să corespundă întru câtva raportului dintre numeroasele contexte funerare getice, timpurii şi cele câteva morminte încadrate în perioada târzie a Latèneului (în acest sens: Alexandrescu 1972, 15-17 şi observațiile critice ale lui Babeş 1988, 8, n. 15). Ar mai trebui reținută şi menționarea pasageră a unor obscure materiale databile în secolul I p.Chr., cărora le-ar putea corespunde cronologic singurul context funerar de la Zimnicea care conține piciorul unei fibule linguriță (Alexandrescu 1972, 19, 26, pl. VI, 3; Alexandrescu 1980, 26, 121, fig. 76/16). In general, se poate observa că în cercetare, sincronizarea dintre fazele de locuire din aşezare şi cele de înmormântare din necropolă a fost poate prea puțin argumentată, dar nu a fost niciodată contrazisă: puținele materiale descoperite pe "Cetate" şi menţionate în literatură pledează cu prisosință în acest sens.

Problemele neelucidate ale cercetărilor mai vechi. $\mathrm{O}$ sintetizare a stadiului actual de publicare a rezultatelor cercetărilor desfăşurate de-a lungul timpului în aşezarea de epocă Latène de la Zimnicea nu s-ar putea încheia fără precizarea unora dintre nerealizările, neajunsurile sau lacunele care se vădesc în literatura dedicată acestui sit. $\mathrm{Nu}$ dorim ca prin aceasta să lezăm în vreun fel memoria sau prestigiul înaintaşilor, dar considerăm că un astfel de demers este necesar pentru punerea în valoare a datelor cunoscute față de cele rămase necunoscute şi pentru a desluşi priorităţile şi scopurile unor cercetari viitoare.

In ciuda unei aparente circumscrieri pe criterii geomorfologice a aşezării de epocă Latène de la Zimnicea, trebuie subliniat faptul că limitele locuirii getice nu au fost îndeajuns evidențiate până acum. In contribuțiile dedicate ansamblurilor funerare din afara "Cetății" nu a fost precizat dacă eventuale contexte de locuire Latène se continuă pe "Câmpul morților", în zona de tereasă aflată la est, spre gospodăriile localității actuale, acolo unde se situează o bună parte dintre secțiunile trasate de Alexandrina Alexandrescu $^{51}$. De asemenea, pe porțiunea de

\footnotetext{
${ }^{51}$ Mai precis, suprafețele C3, C13, C15, C17, a căror amplasare este indicată în planul general oferit de Alexandrescu 1980, 57, fig. 1. Remarca lui Nestor 149, 119, potrivit căruia la Zimnicea s-ar fi aflat un "sat" extins în jurul unei cetăți apărate cu şanțuri ar putea fi coroborată cu observația potrivit căreia la sfârşitul fazei a II-a de existență a aşezării, "fortificația" ar fi fost
} 
terasă a Dunării situată la nord de "Cetate", între aceasta și via în care a fost identificată necropola din epoca bronzului timpuriu (suprafața $\mathrm{C} 18)^{52}$, nu s-au efectuat cercetări, astfel că pentru o posibilă continuare sau nu a locuirii Latène din această porțiune de teren nu dispunem de nici un fel de indicii. $\mathrm{Cu}$ alte cuvinte, la ora actuală nu dispunem de o delimitare netă a suprafețelor locuite de-a lungul epocii Latène. Din această perspectivă însăşi departajarea tradițională a terenului aflat la vest de Zimnicea actuală în "Cetate" şi "Câmpul morților" ar trebui privită cu unele rezerve.

Nici originea antropică ("artificial") a şanțului care ar fi delimitat aşezarea nu a fost suficient argumentată $^{53}$, iar existența acelor "palate-turnuri" întărite, amenajate din bârne şi blocuri nefasonate de piatră a fost doar afirmată, dar informații explicite legate de modul de constituire al acestor construcții sau amenajări, date referitoare la dimensiunile sau

abandonată (Alexandrescu 1974a, 56). Pe baza acestor afirmații am putea deduce, fără să dispunem însă de argumente certe, că locuirea getică s-ar fi extins cel puțin în anumite faze ale existenței aşezării şi dincolo de "valea" şi "şanțul" care mărginesc "Cetatea".

${ }^{52}$ Această zonă rămasă necercetată cu exceptia micului sondaj din suprafața $\mathrm{C} 5$, se întinde pe o distanță de aproape jumătate de km pe direcție nord-sud şi se află la vest de drumul modern care mărginește suprafețele C2, C6, C10 şi C19.

${ }^{53} \mathrm{O}$ situație poate în bună măsură similară celei de la Zimnicea ar putea fi percepurtă în descrierea de către Preda 1986, 30-31, 19, fig. 6 a situației de la Sprâncenata unde "în partea de est (...) s-a creat o viroagă naturală ... Aceasta a fost adâncită de locuitorii așezării, transformând-o în şant de apărare. Pământul rezultat din săparea şanţului a fost depus pe marginea dinspre interior a acestuia...". In mod straniu, în profilele ilustrate de Preda, solul virgin de la baza depunerilor arheologice nu a fost indicat în vreun fel, iar umplutura "valului" prezintă aceiaşi haşură cu cea reprezentată pe fundul şanțului, astfel că ne putem lesne pune întrebarea dacă nu cumva dava de la Sprâncenata nu va fi fost la fel de "temeinic" fortificată ca şi aşezarea de la Zimnicea. Din profilele publicate de Preda nu reiese decât existența unor terasări, nicidecum a unei fortificații. Dacă mai adăugăm şi faptul că "valul" de la Popeşti datează din bronzul târziu (Palincaş 1996, 281-284) sau cel puţin este anterior culturii Basarabi (Vulpe 1965, 106), iar aşezarea de la Cârlomăneşti, plasată şi ea pe un promontoriu distinct, nu pare să fi fost nici ea prevăzută cu fortificații (Babeş 1975, 125), problema sistemelor defensive ale aşezărilor de epocă târzie Latene din sudul Daciei ar trebui abordată cu mai mult spirit critic. aspectul lor au rămas inedite. Această constatare este valabilă şi pentru oricare alte amenajări (locuințe mai mici, ateliere ş.a.) care vor fi fost identificate la Zimnicea, dar despre caractreristicile cărora nu ştim astăzi nimic. Dezvelirea şi cercetarea unor mari suprafețe, pe cuprinsul cărora s-ar fi putut studia integral resturile unor asemenea locuințe cu funcțiunile şi dependințele lor, preconizate inițial de Nestor (Nestor 1949, 118), au rămas din păcate simple deziderate.

Prezentarea stratigrafiei de la Zimnicea, în ciuda descrierii ei schematice, dar sistematice de către Nestor, este totuşi mai puțin convingătoare în absența din publcații a unei documentatiii ilustrate explicite. De asemenea, se poate pune întrebarea dacă observațiile stratigrafice efectuate de Nestor pe baza săpăturilor desfăşurate mai ales în nordul, dar şi sud-estul sitului (unde însă cercetarea suprafețelor deschise nu a fost finalizată) sunt sau nu valabile şi pentru alte părți ale "Cetății", cum ar fi de exemplu zona sa centrală, traversată de secțiunea magistrală S.XVIII deschisă în 1975 (v. anexa şi fig. 2), a cărei cercetare a rămas la rândul ei inedită.

Aceiaşi obiecție se poate face şi în cazul interpretărilor stratigrafice efectuate de către Radu Vulpe şi Alexandrina Alexandrescu. La data la care aceştia afirmau (în 1966 şi în 1974) incendierea de patru şi respectiv de cinci ori a aşezării getice, zona centrală a sitului Cetate nu fusese încă sondată şi cercetată. Prin urmare, acele indicii care ar fi sugerat celor doi acele incendii catastrofale nu au putut fi urmărite pe întreaga suprafață a sitului, nici măcar măcar pe o bună parte a acestuia. Până la o verificare prin publicarea rezultatelor unor noi săpături a valabilităţii identificării "catastrofelor" care ar fi sigilat fiecare dintre nivelurile aşezării, trebuie ținut seama de faptul că Nestor nu a efectuat nici cea mai mică aluzie în privința unor distrugeri provocate prin incendiu, fie dintr-o anumită prudență în afirmații, fie din motivul unei reale evidențe contrarii. Din păcate, cercetarea actuală nu dispune de o imagine concludentă şi mai ales concretă asupra stratigrafiei aşezării getice de la Zimnicea, în lipsa unor relevee edite ale profilelor secțiunilor cercetate, iar imposibilitatea reconstituirii repartiției stratigrafice a 
unor elemente de datare, precum amforele ştampilate, îngreunează substanțial o eventuală aprofundare a stadiului informațional actual ${ }^{54}$. Corelarea strânsă dintre succesiunea stratigrafică şi lanțul evenimentelor majore ale unei istorii de patru veacuri la Dunărea de Jos, aşa cum o propunea Alexandrina Alexandrescu, este mai degrabă suspectă, tocmai în absența valorificării şi publicării documentaţiei privind succesiunea şi dinamica depunerilor care alcătuiesc stratigrafică sitului "Cetate".

Trebuie subliniat faptul că dintre materialele care vor fi fost recoltate din aşezarea de epocă Latène de-a lungul mai multor campanii (1924, 1948-1949, 1967-1975, în total 12 campanii !), nu au fost prezentate în literatura de specialitate în mod sistematic (ilustrate şi descrise) decât neaşteptat de puține piese ceramice, iar strădania publicării lor o datorăm lui Pârvan, Irinei Casan-Franga şi lui Dumitru Tudor ${ }^{55}$. Din păcate, materialele ceramice precum amforele ştampilate greceşti, indicatori cronologici de primă importanţă, dar şi cupele cu decor în relief, nu au fost şi nu mai pot fi raportate la schema stratigrafică propusă

\footnotetext{
${ }^{54}$ Revizuirea de către Nicolae Conovici a datării seriilor de astinomi din grupele V-VI, aşa cum le propunea Grakov face ca amforele sinopeene târzii să nu mai constituie elemente de datare pentru secolul I a.Chr. Potrivit lui Conoivici 1998, 40 şi 50-51, emiterea de ştampile amforice a încetat la Sinope odată cu supunerea cetății de către Pharnaces I, în primele decenuii ale secolulul al II-lea a.Chr. Prin urmare, ştampila amforică pe care Tudor 1967, 43, nr. 138 o încadra în grupa a VI-a după Grakov (120-70 a.Chr.) şi pe care o invoca pentru argumentarea continuării locuirii de pe "Cetate" și în secolul I a.Chr., nu mai constituie un element de datare convingător.

55 După cum am arătat mai sus, câteva mostre de ceramică locală la roată și un kantharos de import au fost ilustrate în Getica lui Pârvan; numai fibula tracică din S.XIV și capacul cu impresiunea unei astfel de fibule din S. IV au fost descrise şi ilustrate de A. D. Alexandrescu. Numai pentru cele din urmă piese s-au oferit extrem de sumare date referitoare la contextul descoperirii. Dacă amforele ştampilate descoperite în săpăturile din 1924 şi 1948-1949 au fost publicate de Tudor 1967 (v. supra n. 21 şi 53), cele identificate în campaniile 1966-1975 sunt inedite. Şi în privința cupelor locale cu decor în relief publicate de CasanFranga (v. supra n. 47), trebuie subliniată lipsa informațiilor legate de contextele de descoperire. Pentru moneda emisă la Odessos, singura identificată prin săpături sistematice pe "Cetate", v. supra n. 43. Pentru alte descoperiri monetare întâmplătoare realizate după toate probabilitățile pe acelaşi sit, v. infra n. 87 .
}

de Nestor decât în mod pur ipotetic. In stadiul actual al cercetării, nu dispunem de indicatori cronologici consistenți și relevanți din punct de vedere numeric pentru susținerea unei continuități neîntrerupte de locuire pe "Cetatea" de la Zimnicea din secolul al IV-lea până în secolul I a.Chr. (sau poate chiar până în sec. I p.Chr.?), la fel cum posibile discontinuități de locuire nu pot fi nici ele temeinic argumentate.

Spre deosebire de importuri, produsele ceramice locale descoperite pe "Cetate" au fost prea puțin, dacă nu deloc prelucrate şi valorificate, deşi caracterul multistratificat al sitului ar fi putut permite eventual întocmirea unui studiu dedicat repartitiei pe niveluri a formelor ceramice. Pe bună dreptate, Alexandru Vulpe afirma recent despre "Cetatea" de la Zimnicea că "masiva depunere arheologică, numeroasele urme de locuințe şi cantitatea mare de material ceramic sunt elemente ce conferă importanță acestei aşezări...” (Vulpe 2001, $481)^{56}$. Trebuie însă precizat faptul că marea cantitate de materiale ceramice este încă inedită, iar pentru aspectul locuințelor getice suntem în continuare constrânşi să ne mulțumim cu mențiunile succinte ale lui Pârvan şi cu afirmațiile ambigue ale lui Ion Nestor şi Radu Vulpe.

De asemenea, dintre materialele metalice identificate în nivelurile de locuire de epocă Latène nu este cunoscută la ora actuală decât o singură fibulă tracică şi mai sus amintita monedă de la Odessos, ceea ce, să recunoaştem, reprezintă surprinzător de puțin, în raport cu amploarea săpăturilor desfăşurate în aşezarea de pe "Cetate" (Mitrea 1965, 241-242) , $^{57}$ pe de o

\footnotetext{
${ }^{56}$ Rămâne încă neconfirmată opinia lui Vulpe A. 1970, 145 , n. 97 , potrivit căreia nivelurile cele mai vechi de locuire de la Zimnicea ar conține materiale ceramice analoge celor din faza târzie (III) de la Ferigile. O sugestie similară o regăsim şi la Moscalu 1983, 186.

57 B. Mitrea atrăgea atenția asupra raportului disproporționat între suprafața totală a sitului şi suprafațele cercetate de Nestor (acestea ar fi reprezentat doar "o mică fracție" din suprafaţa întregii aşezări). Astăzi, când resursele financiare rezervate arheologiei sunt incomparabil mai mici decât cele de care dispunea Nestor în 1948-1949, amploarea suprafetelor cercetate pe atunci este mai degrabă impresionantă. Pe de altă parte, majoritatea monedelor care ar fi fost descoperite pe "Cetate" de-a lungul timpului provin din descoperiri fortuite. Pe lângă monedele publicate acum aproape patru decenii de Mitrea 1965, 249-256, nr. 5, 6, 8, 12,
} 
parte, şi cu diversitatea şi cantitatea remarcabilă de de materiale provenind din necropola getică de pe "Câmpul morților" învecinat. Desigur, este greu de precizat dacă această conjunctură este rezultatul cercetării unui ansamblu de locuire sărac în obiecte metalice sau expresia directă a lipsei de valorificare şi publicare a materialelor de la Zimnicea. Nu trebuie pierdut din vedere însă şi faptul că, spre deosebire de vestigiile locuirii getice pentru care în literatura de specialitate se oferă unele indicii, despre prezența unor locuințe medievale pe "Cetatea" de la Zimnicea singura informație concretă este aceea a atestării lor ${ }^{58}$.

In condițiile în care documentația arheologică primară a mai multor generații de arheologi care şi-au adus contribuția la cercetarea unui sit atât de complex a dispărut odată cu autorii ei, reinițierea unor cercetări pe "Cetatea" de la Zimnicea este văduvită de numeroase date tehnice concrete ale vechilor săpături ${ }^{59}$. De asemenea, în absența unor informații consistente referitoare la contextele arheologice identificate, valorificarea materiallelor recoltate de-a lungul timpului din secțiunile efectuate pe "Cetatea" de la Zimnicea şi păstrate în instituții de profil din mai multe localități (Muzeul din Alexandria, Muzeul din Giurgiu, Muzeul Național de Istorie a României şi Institutul de Arheologie din Bucureşti) se vădeşte a fi o întreprindere anevoioasă şi cu rezultate prea puțin fructoase pentru cercetare. Regăsirea măcar a unor crâmpeie din documentaţia predecesorilor noştrii şi publicarea lor ca atare ar putea furniza date prețioase pentru întregirea imaginii rezultatelor cercetărilor mai vechi de pe "Cetatea" de la Zimnciea.

(Manuscris finalizat în iunie 2005)
14, 16-18 (micul tezaur de tetradrahme thasiene), 19-22 şi 28-29 (monede din secolul al XIV-lea), recent un lot de şase drahme dyrrhachiene şi trei denari republicani, intrat în comerțul de antichități, se adaugă descoperirilor numismatice întâmplătoare realizate după toate probabilitățile pe "Cetatea" de la Zimnicea (Popescu 1994). Prin contrast cu singura monedă descoperită în mod sistematic, numărul semnificativ de descoperiri numismatice fortuite realizate "la Cetate" sugerează fie că norocul le surâde arareori arheologilor de profesie, fie că identificarea unor obiecte cu valoare mare a fost pusă lesne în legătură de către localnici cu tradiția orală despre existența unei "Cetăți” străvechi.

58 Unele referiri la materialele medievale de la Zimnicea le datorăm totuşi Eugeniei Zaharia căreia îi erau cunoscute forme ceramice medievale şi care arată că acestea se aflau în anii '60 în atenția Alexandrinei Alexandrescu (Zaharia 1967, 159-160, n. 215; Marinescu Bîlcu 1997, 13-14). Menționarea câtorva materiale medievale de la Zimnicea o datorăm aceleiaşi Zaharia 1967, fig. 60/1, 3, 5, precum şi lui, Constantinescu 1972, 52, n. 56, 70, 79, n. 84, 92-93, n. 93,98, n. 107, însă nu ştim dacă referirile celor doi autori vizează inventarul locuințelor cercetate pe "Cetate" sau al celor identificate pe "Câmpul Morților".

\footnotetext{
${ }^{59} \mathrm{O}$ încercare de a dobândi câteva repere suplimentare în comentariul anex la fig. 2 de la sfârşitul demersului de faţă.
} 


\section{LISTA FIGURILOR}

Fig. 1. Zimnicea, siturile "Cetate" şi "Câmpul Morților". Planul general al săpăturii din anii 1948-1949 şi 1966-1975 (după Alexandrescu 1980, 57, fig. 1), cu indicarea noilor săpături (2000-2003).

Fig. 2. Planul sitului Cetate cu săpăturile din 1948-1949 şi 1966-1975 şi cu indicarea locuinţelor medievale. După planşa regăsită la Institutul de Arheologie (v. anexa).

\section{ANEXA. COMENTARIU PE MARGINEA FIG. 2}

Prin amabilitatea Iulianei Barnea, în primăvara anului 2001 s-a reuşit regăsirea mai multor planşe pe calc alcătuind planul general, la scara 1/500, al siturilor "Cetate" şi "Câmpul morților", întocmite probabil de către Anişoara Sion în 1974 şi care zăceau uitate pe un raft din sala Histria a Institutului de Arheologie din Bucureşti. In acest plan au fost indicate curbele de nivel (cu echidistanța de $1 \mathrm{~m}$, măsurate de la o cotă aleasă arbitrar pe apa râului Pasărea), unele repere din teren (locuințe actuale, gardul astăzi dispărut care împrejmuia rezervația arheologică a sitului "Cetate" ş.a.) şi totalitatea secțiunilor cercetate de Ion Nestor şi Alexandrina Alexandrescu, mai puțin secțiunea S.XVIII care străbătea zona centrală a "Cetății" de la est la vest. Această secțiune "magistrală", identificabilă şi astăzi în teren, a fost săpată în anul 1975, potrivit unor informații verbale oferite de Cornelia Stoica şi de George Trohani, dar şi potrivit marcajelor de pe unele materiale ceramice aflate la Muzeul din Alexandria şi care se află la ora actuală în atenția lui Ion Pătraşcu. Pe lângă secțiuni ("S", numerotate cu cifre romane) în planşa respectivă a mai fost indicată şi poziția unor casete ("R", numerotate cu cifre arabe) aflate în partea de est a sitului, de-a lungul potecii care coboară spre sud către luncă.

Indicarea amplasamentului unor locuințe medievale identificate parțial, sau integral în interiorul secțiunilor cercetate de-a lungul timpului pe "Cetate" şi "Câmpul morților", sugerează că planul general regăsit era destinat ilustrării unui studiu dedicat locuirii medievale de la Zimnicea, probabil tocmai acela despre care cu regret aflăm, din necrologul semnat de Marinescu-Bîlcu 1997, 14, că nu a mai putut fi finalizat de Alexandrina Alexandrescu. De asemenea, este posibil ca aceste planşe să fi fost copiate după releveele realizate pe teren în cursul campaniilor coordonate de Ion Nestor şi de Alexandrina Alexandrescu. Astfel de relevee vor fi stat şi la baza planurilor necropolelor preistorice publicate de regretata cercetătoare bucureşteană, şi tot pe baza lor s-a realizat probabil şi planul general din 1980 (Alexandrescu 1980, 57, fig. 1). Din păcate, în acest plan edit, secțiunile cercetate pe "Cetate" nu sunt însoțite de sigle, care însă figurează în planşele inedite regăsite de Iuliana Barnea. Fie şi numai din acest motiv - şi anume indicarea poziției în sit a secțiunilor cu siglele aferente (până acum inedite), planşa regăsită a sitului "Cetate" îşi susține importanța şi valoarea documentară, astfel că am considerat necesară reproducerea ei în demersul de față (fig. 1). Numai poziția secțiunii XVIII/1975 am aproximat-o pe baza planului general publicat de Alexandrina Alexandrescu, fără să am însă posibilitatea de a verifica existența şi eventual amplasarea unor locuințe medievale pe cuprinsul ei.

După cum reiese din distribuția secțiunilor, dacă Nestor care îşi concentrase atenția în nordul şi sud-estul "Cetății", Alexandrina Alexandrescu a fost preocupată mai ales de cercetarea zonei mai înalte din nord-estul sitului (S. VIII, XII-XV şi XVII), ca şi de partea sa centrală (S. XVIII) şi mai puțin de extremităţile de nord-vest (S. XVI şi XVIa) sau sud-est (S. X şi XI). Se poate pune întrebarea dacă nu cumva, secțiunile efectuate de Alexandrina Alexandrescu în zona de nord-est a "Cetății" nu vor fi suprapus tocmai acele "şanțuri înguste" ale săpăturii lui Andrieşescu. De asemenea, prin modul de amplasare a secțiunilor VIII, XII-XV şi XVII, putem bănui că cercetătoarea bucureşteană ar fi putut sesiza existența unor eventuale structuri de fortificație, ca cele de la Coțofenii din Dos sau ca cele de la Tinosu. Putem lesne bănui că identificarea unor astfel de structuri şi-ar fi găsit ecoul în contribuțiile Alexandrinei Alexandrescu, fie şi numai sub forma unor simple menţiuni.

Trebuie remarcat numărul sporit de 17 locuințe medievale identificate pe platoul "Cetății" şi care se dovedeasc a avea dimensiuni mari (4-5 m latura). Totuşi, în majoritatea cazurilor, atât în săpăturile din 1948-1949, cât şi în săpăturile Alexandrinei Alexandrescu, locuințele medievale identificate nu par să fi fost cercetate integral, prin deschiderea unor casete laterale (excepție fac numai locuințele 45 din R4, 46 din R6 şi 40 din R1, dar acestea se situează în afara platoului înalt al "Cetății"). In general, metoda de săpare adoptată - trasarea de şanțuri lungi adaptate la panta terenului sau, în cazul şanțului XVIII, 
secționarea întregului sit - sugerează preocuparea precumpănitoare pentru evidențierea stratigrafiei aşezării, şi, într-o mai mică măsură, dacă nu deloc, pentru dezvelirea unor suprafețe întinse şi implicit, pentru cercetarea exhaustivă a unor construcții (locuințe, ateliere sau alte amenajări), fie ele getice sau medievale.

Ar mai trebui semnalat că în planşa inedită originală a fost haşurată o suprafaţă întinsă din colțul de nord-est al "Cetății", care corespunde în teren, potrivit informațiilor d-lui Corneliu Beda şi observațiilor personale efectuate pe teren, cu o imensă excavație modernă realizată după toate probabilitățile la începutul anilor '70 prin mijloace mecanizate: pământul excavat era destinat unor lucrări de îmbunătățiri funciare. $\mathrm{Cu}$ acea ocazie, zona mai înaltă din nord-estul sitului a fost puternic deranjată, parțial distrusă, astfel încât unele dintre secțiunile trasate aici (de exemplu secțiunile I, XII şi XIV) nici măcar nu mai pot fi reidentificate pe teren la ora actuală.

In încheiere țin să mulțumesc tuturor celor care într-un fel sau altul au contribuit mai ales la salvarea, dar şi la desluşirea informațiilor grafice conţinute pe planşa inedită reprodusă în demersul de faţă: Iuliana Barnea, Cornelia Stoica şi Corneliu Beda, Ion Pătraşcu şi George Trohani.

\section{BIBLIOGRAFIE}

Alexandrescu 1972 - A. D. Alexandrescu, Mormintele din perioada mai tîrzie a necropolei getice de la Zimnicea (jud. Teleorman), Crisia 2, 1972, 15-26.

Alexandrescu 1973 - A. D. Alexandrescu, La nécropole du bronze récent de Zimnicea (dép. de Teleorman), Dacia 17, 1973, 77-97.

Alexandrescu 1974a - A. D. Alexandrescu, Autour des fouilles de Zimnicea, Thracia III (Sofia) 1974, 47 64.

Alexandrescu 1974b - A. D. Alexandrescu, La nécropole du bronze ancien de Zimnicea (dép. de Teleorman), Dacia 18, 1974, 79-93.

Alexandrescu 1976 - A. D. Alexandrescu, À propos des fibules $<$ thraces $>$ de Zimnicea, Thraco-dacica 1, 1976, 131-141.

Alexandrescu 1978 - A. D. Alexandrescu, Sépulture du premier Age du Fer à Zimnicea, Dacia 22, 1978, 115-124.

Alexandrescu 1980 - A. D. Alexandrescu, La nécropole gète de Zimnicea, Dacia 24, 1980, 19-126.

Alexandrescu 1983 - A. D. Alexandrescu, Tombes de chevaux et pièces de harnais dans la nécropole gète de Zimnicea, Dacia 27, 1983, 67-78.

Babeș 1975 - M. Babeş, Problèmes de la chronologie de la culture géto-dace à la lumière des fouilles de Cîrlomăneşti, Dacia 19, 1975, 125-139.

Babeş 1988 - M. Babeş, Descoperirile funerare şi semnificația lor în contextul culturii geto-dacice clasice, SCIVA 39, 1, 1988, 3-32.

Babeș 1997 - M. Babeş, Despre fortificațiile "Cetăţii Jidovilor" de la Coțofenii din Dos, SCIVA 48, 3, 1997, 237-254.

Babeş 2001 - M. Babeş, Spațiul carpato-dunărean în secolele III-II a.Chr., M. Petrescu-Dâmbovița, A. Vulpe, Istoria românilor, vol. I, Moştenirea timpurilor îndepărtate, Bucureşti, 2001, 501-532.

Babeş et alii 2001 - M. Babeş, G. Trohani, D. Spânu, I. Pătraşcu, Zimnicea, jud. Teleorman, Cronica cercetărilor arheologice din România, Campania 2000, Bucureşti, 2001, 276-277, nr. 232.

Babeş et alii 2002 - M. Babeş, D. Spânu, G. Trohani, I. Pătraşcu, Zimnicea, jud. Teleorman, Cronica cercetărilor arheologice din România - campania 2001, Bucureşti, 2002, 344-345, nr. 248.

Bertrand 1876 - A. Bertrand, Archéologie celtique et gauloise, Paris, 1876.

Boia 1997 - L. Boia, Istorie şi mit în conştiința românească, Bucureşti, 1997.

Bolliac 1872 - C. Bolliac, Arheologie. Ceramică, Trompeta Carpaților 10/965, 1872, 1-2.

Bolliac 1874 - C. Bolliac, Ceramica Daciei. Câmpul morților de la Zimnicea, Trompeta Carpaților 12/1137, 1874, 1-2.

Casan-Franga 1967 - I. Casan-Franga, Contribuții la cunoaşterea ceramicii geto-dacice. Cupele "deliene" getice de pe teritoriul României, Arheologia Moldovei 5, 1967, 7-35. 
Conovici 1998 - N. Conovici, Les timbres amphoriques. 2. Sinope (tuiles timbrées comprises). Alexandrescu P., Histria 8, Bucureşti, 1998.

Constantinescu 1972 - N. Constantinescu, Coconi, un sat din Cîmpia română în epoca lui Mircea cel Bătrîn. Bucureşti, 1972.

Curinschi Vorona 1981 - G. Curinschi Vorona, Istoria arhitecturii în România, Bucureşti, 1981.

Daicoviciu 1960 - C. Daicoviciu, Perioada Burenbista-Decebal, Istoria României, vol. 1, Bucureşti, 1960, 255-338.

Dumitrescu 1934 - V. Dumitrescu, Un vase délien d'importation trouvé près de Fundeni, In memoria lui Vasile Pârvan, Bucureşti, 1934, 121-125.

Dumitrescu 1993 - V. Dumitrescu, Oameni şi cioburi. Contribuții la istoria contemporană a arheologiei româneşti, Cultură şi civilizație la Dunărea de Jos 11, Călăraşi, 1993.

Endert 1987 - D. v. Endert, Das Osttor des Oppidums von Manching, Die Ausgrabungen in Manching 10, Stuttgart, 1987.

Iosifaru 2003 - M. Iosifaru, Ceramica ştampilată din județul Vâlcea, Studii Vâlcene 8, 2003, 36-41.

Marinescu Bîlcu 1997 - S. Marinescu Bîlcu, Alexandrina Dumitra Alexandrescu (necrolog), SCIVA 48, 1, 1997, 11-16.

Matei 1979 - M. D. Matei, Cercetarea arheologică a satului medieval românesc în secolele XII-XIV: realizări, perspective, sarcini, SCIVA 30, 3, 1979, 411-425.

Măndescu 2001 - D. A. Măndescu, Cezar Bolliac. Pagini uitate din zorii arheologiei româneşti, CICSA - Buletinul centrului de istorie comparată a societăților antice 3, 2001, 17-28.

Meylan, Murus Gallicus - F. Meylan, Murus Gallicus, Reallexicon der Germanischen Altertumskunde 20, 2002, 388-391.

Mitrea 1965 - B. Mitrea, Monede antice şi feudale descoperite la Zimnicea, SCIV 16, 2, 1965, 239-260.

Moscalu 1983 - E. Moscalu, Ceramica traco-getică, Bucureşti, 1983, 192-193.

Nestor 1933 - I. Nestor, Der Stand der Vorgeschichtsforschung in Rumänien, Bericht RGK 22, 1933.

Nestor 1949 - I. Nestor, Săpăturile arheologice de la Zimnicea, jud. Teleorman, Studii 2, 1949, 116-125.

Nestor 1950 - I. Nestor, Aşezările din societate primitivă şi sclavagistă în regiunea Dunărea de Jos, Raport sumar asupra campaniei de săpături arheologice de la Zimnicea, SCIV 1, 2, 1950, 93-120.

Palincaş 1996 - N. Palincaş, Valorificarea arheologică a probelor $14 C$ din fortificația aparținând Bronzului târziu de la Popeşti (jud. Giurgiu), SCIVA 47, 3, 1996, 239-288.

Pârvan 1926 - V. Pârvan, Getica. O protoistorie a Daciei, Bucureşti, 1926.

Popescu 1994 - A. Popescu, Monede greceşti şi romane dintr-un tezaur găsit la Zimnicea, jud. Teleorman. BSNR 86-87, 1992-1993 (1994), 305-307.

Preda 1986 - C. Preda, Geto-dacii din bazinul Oltului inferior. Dava de la Sprîncenata, Bucureşti, 1986.

Protase 1971 - D. Protase, Riturile funerare la daci şi la daco-romani, Bucureşti, 1971.

Spânu 2004 - D. Spânu, Zimnicea, jud. Teleorman, Cronica cercetărilor arheologice din România campania 2003, Bucureşti, 2004, 379-381, nr. 217, p. 467, pl. 77.

Spânu, Trohani 2003 - D. Spânu, G. Trohani, Zimnicea, jud. Teleorman, Cronica cercetărilor arheologice din România - campania 2002,Bucureşti, 2003, 347-348, nr. 224.

Syme 1971 - R. Syme, Lentulus and the Origin of Moesia, In R. Syme, Danubian Papers, Bucureşti, 1971, 40-72.

Tocilescu 1880 - G. G. Tocilescu, Dacia înainte de romani. Cercetări asupra popoareloru carii au locuitu tierile romane de a stang'a Dunarii, mai inainte de concuista acestoru tieri de cotra imperatoriul Traianu, Bucuresci, 1880.

Tudor 1967 - D. Tudor, Amforele greceşti ştampilate în Moldova, Muntenia şi Oltenia, Arheologia Moldovei 5, 1967, 37-80.

Vulpe Zimnicea - A. Vulpe, Zimnicea, Pippidi D. M., Dicționar de istorie veche a României, Bucureşti, 1976, 624.

Vulpe 1965 - A. Vulpe, Zur Mittleren Hallstattzeit in Rumäniei (die Basarabi-Kultur), Dacia 9, 1965, $105-132$

Vulpe 1970 - A. Vulpe, Archäologische Forschungen und historische Betrachtungen über das 7. bis 5. Jh. Im Donau-Karpatenraum, Memoria Antiquitatis 2, 1970, 115-185. 
Vulpe 2001 - A. Vulpe, Istoria şi civilizația spațiului carpato-dunărean între mijlocul secolului al VII-lea şi începutul secolului al III-lea a.Chr. M. Petrescu-Dâmboviţa, A. Vulpe (ed.), Istoria românilor, vol. I, Bucureşti, 2001, 451-500.

Vulpe, Gheorghiță 1976 - A. Vulpe, M. Gheorghiță, Bols à relief de Popeşti, Dacia 20, 1976, 167-198.

Vulpe 1960a - R. Vulpe, Prima perioadă a culturii geto-dace (circa 450 - 300 î.e.n.), Istoria României, vol I, Bucureşti, 1960, 223-231.

Vulpe 1960b - R. Vulpe, Muntenia şi Moldova în epocă romană, Istoria României, vol I, Bucureşti, 1960, 517-530.

Vulpe 1960c - R. Vulpe, Les Gètes de la rive gauche du Bas Danube et les Romains, Dacia 4, 1960, 309-332.

Vulpe 1966 - R. Vulpe, Aşezări getice din Muntenia, Bucureşti, 1966.

Vulpe 1976 - R. Vulpe, Les gètes de la rive gauche du Bas-Danube et les Romaines, R. Vulpe, Studia Thracologica, Bucureşti,1976, 124-149.

Vulpe, Dunăreanu-Vulpe 1924 - R. Vulpe, E. Dunăreanu-Vulpe, Les fouilles de Tinosul, Dacia 1, 1924, 166-223.

Zaharia 1967 - Zaharia E., Săpăturile de la Dridu. Contribuție la arheologia şi istoria perioadei de formare a poporului român. Bucureşti, 1967.

Zirra et alii 1993 - V. Zirra, N. Conovici, G. Trohani, P. Gheorghe, P. Alexandrescu, G. Gâță, V. Zirra, La station gétique fortifiée de Cetatea Jidovilor (Coțofenii din Dos, dép. de Dolj), Dacia 37, 1993, 79-158.

\section{Abbildungen:}

Abb. 1. Zimnicea - die Fundstellen "Cetate" und "Câmpul Morților". Gesamtplan der Ausgrabunden: 1948-1949, 1966-1975 (mach Alexandrescu 1980, 57, Abb. 1) und 2000-2003 (neue Ausgranungen M. Babeş).

Abb. 2. Plan der untersuchten Flächen auf der Fundstelle "Cetate" von Zimnicea (1948-1949 und 19661975) mit Kartierung der mittelalterlichen Hütten.

\section{Daniel Spânu}

Institutul de Arheologie "Vasile Pârvan"

Str. Henri Coandă nr. 11, Bucureşti

Tel./Fax: 212.88.62

hazdrik@yahoo.com 